\title{
Characterization of the Clay Masonry Units and Construction Technique at the Ancient City of Nippur
}

DOI:

10.1016/j.engstruct.2017.06.017

\section{Document Version}

Accepted author manuscript

Link to publication record in Manchester Research Explorer

\section{Citation for published version (APA):}

Al-Sibahy, A., \& Edwards, R. (2017). Characterization of the Clay Masonry Units and Construction Technique at the Ancient City of Nippur. Engineering Structures, 147, 517-529. https://doi.org/10.1016/j.engstruct.2017.06.017

\section{Published in:}

Engineering Structures

\section{Citing this paper}

Please note that where the full-text provided on Manchester Research Explorer is the Author Accepted Manuscript or Proof version this may differ from the final Published version. If citing, it is advised that you check and use the publisher's definitive version.

\section{General rights}

Copyright and moral rights for the publications made accessible in the Research Explorer are retained by the authors and/or other copyright owners and it is a condition of accessing publications that users recognise and abide by the legal requirements associated with these rights.

\section{Takedown policy}

If you believe that this document breaches copyright please refer to the University of Manchester's Takedown Procedures [http://man.ac.uk/04Y6Bo] or contact uml.scholarlycommunications@manchester.ac.uk providing relevant details, so we can investigate your claim.

\section{OPEN ACCESS}




\title{
Characterization of the Clay Masonry Units and Construction Technique at the Ancient City of Nippur
}

\author{
Adnan Al-Sibahy ${ }^{(1,2)^{*}}$, Rodger Edwards ${ }^{(1)}$ \\ ${ }^{(1)}$ School of Mechanical, Aerospace and Civil Engineering, The University of Manchester, Manchester, \\ M13 9PL, United Kingdom. \\ ${ }^{(2)}$ Civil Engineering Department, College of Engineering, The University of Al-Qadisiyah, Iraq.
}

\begin{abstract}
This paper describes a programme of experimental measurements performed in support of a parallel programme of field investigations to evaluate the construction methods used at the site of the ancient city of Nippur. The experimental programme investigated both the mechanical properties and durability of the ancient clay masonry units used in the construction of buildings at Nippur including tests for dimensional consistency and flatness, density, compressive strength, initial rate of water absorption and thermal properties. The test results have been compared with those for modern brick units available nowadays in Iraq and with hard natural stone samples.

The field investigations showed that the important buildings were constructed using composite walls inclusion firing clay masonry units with two nominal dimensions $(30 \times 30 \times 7) \mathrm{cm}$ and $(30 \times 15 \times 7) \mathrm{cm}(I, w$ and $h$ ). The formulation of working design technique was followed to achieve the member stability under applied loads. Layers of bitumen material were used as a binder for both bed and head joints in order to provide the desired strength level for the masonry wall.

The experimental results show that the ancient brick units and stone samples exceed the tolerance and range of dimensions limits recommended by current EN Standards. Lower density values were recorded for the ancient brick units compared with that for both modern clay brick and stone specimens and these values showed agreement with the modern classification of high density (HD) units. Approximately similar values of compressive strength were observed for both ancient brick units and natural stone samples reaching about $17 \mathrm{MPa}$, whilst modern clay brick samples showed lower compressive strength value suitable for application of partition walls. The initial rate of water absorption increases with an increase of the soaking time, but tends to decrease after 90 minutes for both ancient and modern brick units. Superior performance in terms of thermal conductivity, thermal resistance and durability under fire action were observed for the ancient brick samples compared with modern clay brick and stone samples.
\end{abstract}

Keywords: Nippur city, ancient masonry buildings, mechanical behaviour, durability, brick units

* Corresponding author. Tel:+441613064250

Adnan.hassan@postgrad.manchester.ac.uk; Adnan.alsibahy@qu.edu.iq (A.Al-Sibahy) 
Rodger.edwards@manchester.ac.uk (R. Edwards)

\section{Introduction}

Many past civilizations possessed high levels of skill in what were in some cases unique methods of construction. Many of these ancient skills have been lost and it has been difficult to reproduce their levels in service performance even with the modern techniques adopted nowadays.

One of the most ancient cities in the world is Nippur, which has a recorded history back to 5000 B.C [1]. Some of the landmarks of this city still exist from that era [2]. So, parts of Nippur are thought to predate the Ziggurat of Ur (2600 B.C) and the Pyramids in Egypt (2580 B.C) [3]. The city of Nippur with its many buildings and temples in addition to the earlier library was probably more literate than other towns [1].

The city of Nippur is located in the south of Iraq about $170 \mathrm{Km}$ southeast of capital Baghdad in what was Mesopotamia and approximately midway between the ancient cities of Babylon and Ur [2]. This central location helped Nippur to play an important role in the historical events of the Mesopotamia. The topographical characteristics of Nippur site show a large land with some mounds representing the debris of collapsed buildings with a total area of about 135 hectares [2].

From the archaeological point of view, the civilizations with Nippur are firstly pre-Sargonic era followed by Akkadian, Ur III and Old Babylonian periods. The later history of the city (after the $2^{\text {nd }}$ millennium) indicated it fell under the rule of a number of other civilizations at different time, including Assyrian, Parthian, Sassanid, Seleucid and Persian periods. It also appears that the city was considered to be the seat of the Assyrian Church of the East Christian bishopric [4, 5].

The first archaeological excavation of Nippur was performed under the direction of Sir Austen Henry Layard in 1851. About 38 years after this date, the University of Pennsylvania led a detailed period of work continuing for 11 years which involved four seasons of excavation. A more comprehensive investigation was then conducted by the Oriental Institute of Chicago between 1948 and 1990 with 19 seasons of excavation. All of the previous investigation works were focused upon the archaeological objects such as tracing the site and borders of buildings as well as the pottery, documents written on clay tablets $[1,6]$. Today, the overall site is covered by sand dunes, so the monuments of the aforementioned excavations disappeared.

The dominant character of Nippur construction is the historical masonry using clay brick units as no stone was readily available in this area [7]. Brick units were being made by hand in moulds using a particular technique incorporating insertion of the air-dry units into a clamp containing brushwood soaked with fuel and the outside covered with a layer of clay in order to reduce heat loss [3]. The quality of the bricks produced is influenced by the firing time and how well the heat is distributed within the clamp. A well designed mortar to give the required strength and providing uniform bedding for masonry units was used and its quality highly depends on the importance of the structure. It could be as a bitumen, clay-straw mixture or clay mortars [3]. Such mortars were found to be used in construction of 
the Ekur Ziggurat, temples, the main surrounding wall and houses respectively. The composition of mortars, water content used for mixing and temperature level at which the bitumen can fairly flow are the main factors governing the weathering characteristic and resistance of these to the exposure conditions.

The clay bricks of the composition used in Nippur and Mesopotamia civilizations are encountered in other ancient buildings in the world, for example in ancient Greece at the fourth century BC and that used in Portuguese monuments dated to the period of 12th-18th centuries. Previous studies have described the methodology of producing fired bricks used in the former buildings in four stages [8, 9]. The first stage incorporates selection of an appropriate soil as a raw material which is usually clay. Crushing process and mixing with water using suitable water content are the main operations of the second stage. In the third stage, the clay mixture is casted in the moulds then demoulded after stiffing and dried in a covered space. Finally, the bricks allows for sun dried and then putted in a kiln or clamp with a temperature up to $1000{ }^{\circ} \mathrm{C}$.

In general mechanical, the physical, thermal, mineralogical and durability properties of clay bricks and their masonry structures are affected by the raw clay, weathering mechanism, material aging and long term behaviour. The former effects are usually by the action of atmospheric agents such as wind and water [8-10].

Although the great historical value of the ancient Nippur city and its long historic period is widely recognised, there appear to have been no scientific research conducted in investigation the construction techniques followed at this city. This study considers the first attempt to evaluate the old construction of Nippur through two approaches: site investigation and experimental measurements on the materials used in that construction. This gives an opportunity to explore the composition of materials used, skills of old builders and level of their engineering thinking. A comparison has also been made with the modern materials used nowadays (brick and stone) by adopting the relevant EN standards, and evaluating the applicable ranges and limitations for using modern codes of practices on the outputs of ancient construction techniques.

\section{Site investigations}

The whole site is covered by sand dunes at the present. This is due to the conversion of the soil of the site to the sandy soil resulting from the environmental effects and desiccation of the main ancient canal river (Shatt-en-Nil) at this area [2]. Moreover, the city is located at the main sedimentation plains area of

Iraq. So, it was difficult to perform the detailed investigation for the method of construction. On this basis, the evaluation was limited by observing the apparent structures (Ekur Ziggurat) with helps of excavations data published by Oriental Institute of Chicago [1, 4, 6, 11-13].

The Ekur Ziggurat represents the major element in the site with a height reached about $15 \mathrm{~m}$ above of the ground level. It located at the eastern north regain of the site, as shown in Figure 1a $[1,2]$. 
The base of the Ekur Ziggurat occupies a rectangular space of about $2400 \mathrm{~m}^{2}(60 \times 40) \mathrm{m}$. There are five levels linked together through a main staircase to reach the terrace element located at the top of Ziggurat, as shown in Figure 2 [2]. The latter element incorporated some openings in the walls of the Ekur Ziggurat for example to the King's chamber of about 1-1.5 m in width and these openings were constructed without lintel or beams, as shown in Figures $1 \mathrm{~b}$ and $3 a$. This is by following equilibrium aspect when brick units set into wall or so-called grading technique. This allows for supporting the masonry above openings when the thrust line of the inclined upper part of opening produces allowable stresses due to a uniform end bearing [3]. The same manner was also adopted in performing the roof, as shown in Figure $3 \mathrm{~b}$. The roof opening could then be closed by tree legs or grass, and then covered by a clay layer.

Two types of clay bricks were apparently used: sun-dried and firing bricks. The first type was widely used for normal buildings such as houses and made by allowing the brick lumps to drying out in the air or the sun. This may take long time to achieve the strength and usually do not need high quality control. The firing bricks were produced under fire effect within likely a clay-chamber with more efforts in order to get bricks with low variations in quality and sizes [3]. The latter was used in the significant buildings such as temples and Ziggurat.

The construction technique used on Ziggurat involved increasing the width of the wall as to be able to reach the total height of the building. In some regions, the wall thickness was about $1 \mathrm{~m}$ or more. This concept is consistent with the so-called working design technique which gives a range of safety in dimensions of the member in order to obtain the structural stability. If levels- 1 to 5 , shown in Figure 2, were filled with a clay soil and assumed to be solid, the vertical transmission dead loads from the top of King's chamber to the base of Ziggurat can be simply calculated based upon the available dimensions, density of clay soil $\left(14.4 \mathrm{kN} / \mathrm{m}^{3}\right)$ [14] and results of densities presented in Section $4-2$, as shown in Table 1.

It can be seen that the total vertical transmission dead load is $264705 \mathrm{kN}$. This equivalent to a distributed vertical load at the base of the Ziggurat of $110.3 \mathrm{kN} / \mathrm{m}^{2}$. If the latter calculated load is compared with the average bearing capacity of soil near the city of Baghdad (125 kN/m²) [14], the whole Ziggurat building is considered as a stable structure. This manner can be accepted if no allowance for bending moment due to the load eccentricity is permitted. The aforementioned concept was taken into the consideration at construction of this building where the centre of gravity of the whole Ziggurat coincides with its centroid due to its symmetrical shape about the main axis.

Most of the exterior walls of the Ziggurat were fabricated as composite walls, as shown in Figure 4 . The used of composite walls have many advantages, which include, reduction the implementation cost by using clay as a mortar of grout to fill the cavity between the external and internal wall leafs; improving thermal insulation of the wall and increasing the speed of construction [15]. 
The external leaf of the wall was created using bricks with two nominal dimensions $(30 \times 30 \times 7) \mathrm{cm}$ and $(30 \times 15 \times 7) \mathrm{cm}$. This allows for tying similar to the running bond (half bond), as shown in Figures 5 and 6 , so, it would be suitable to call this tying as Nippury bond. Header courses were used to connect both internal and external leafs at different levels.

For the important buildings (such as Ekur Ziggurat), bitumen was used as a binder material, as shown in Figure 7. The composite of masonry (the clay brick units and the bitumen) provided high adhesion for the wall with good strength and high resistance to the effect of the harsh environment. The use of such a construction explains why this building still exists for a long period of time. Other buildings at Nippur constructed with clay mortar did not show similar durability. Another important point should be noted namely that bitumen material requires more attention during construction work especially with high temperatures needed to convert it into the liquid status.

In addition to the main rectangular staircase which leads upward to the top of Ziggurat, the authors have noted a secondary staircase with elliptical configuration leading to level-1. The latter allows accessing the basement of Ziggurat, as shown in Figures 2 and 8. It has an attractive impression and constructed as two circles with different radiuses $(1.25 \mathrm{~m}$ and $0.8 \mathrm{~m})$ connected at two tangents points. This is indicative for the high expertise of the ancient builders.

\section{Details of the experimental programme}

An experimental investigation was carried out in order to evaluate the mechanical and durability performance of the materials used in the construction of the ancient Nipper city. Due to losing its cohesion and adhesion properties due to environmental degradation, the bitumen material showed crumbling, with consequent loss of mechanical integrity. Therefore, it was highly problematic to investigate its behaviour in a useful manner during the investigations. On this basis, the experimental measurements were limited to the clay brick units.

Some of the ancient bricks had Cuneiform writing on them; so, nondestructive tests were performed using full scale bricks in order to keep their archaeological value. On the other hand, destructive tests were carried out on fragments of bricks which had no archaeological value. The experimental tests include those for dimensions and flatness, density, compressive strength, Initial rate of water absorption and thermal properties. All of these tests were performed according to the relevant EN standards.

For the purpose of evaluating the overall mechanical behaviour and meet the objective of this study, the results obtained have been compared with the tested results of modern clay bricks and with those of cubic hard natural stones. The modern clay brick specimens were perforated in shape and taken from a fully automatic factory at the southern part of Iraq with a minimal efflorescence feature as well as produced under high quality control. On the other hand, stone specimens were limestone in nature and taken from a quarry located in an area between Nippur and ancient Ur and available as irregular big lumps. In order to perform the experimental tests, the big lumps of stone were refined into small cubic 
samples. Such compression with the former masonry units gives an indication about the overall performance of the ancient clay brick units used in construction of Ekur Ziggurat.

\section{3-1. Dimensional and flatness tests}

The dimensions and flatness of two types of ancient clay brick configurations, stone and modern clay brick samples were measured according to the EN 772-16 [16] and EN 772-20 [17] respectively. An appropriate measuring tape conforming to the precision given in EN 772-16 was used. The length (lu), width (Wu) and height (hu) of the unit were calculated at the midpoint using a calliper with overlapping jaw aligned along the centre line of the specified unit edge to the nearest $0.5 \mathrm{~mm}$. The procedure described in EN 772-20 [17] was followed to measure the mean deviation in diagonal dimensions of the bed face as well as the greatest distances of concave and convex from the unite surface. The latter measurements were carried out using graduated straight edge and feeler gauge.

\section{3-2. Density}

Density was in accordance with EN 772-13 [18]. The net and gross dry densities of clay masonry units were determined for the representative portions of whole unit specimens. The samples were dried in ventilated oven at temperature of $70{ }^{\circ} \mathrm{C} \pm 5{ }^{\circ} \mathrm{C}$ and $100 \pm 5{ }^{\circ} \mathrm{C}$ for stone and clay samples respectively. The net dry density was calculated using the following Equation [18]:

$\rho_{n, u}=\frac{m_{d r y, u}}{V_{n, u}} \times 10^{6} \quad\left[\mathrm{~kg} / \mathrm{m}^{3}\right]$ Eq. 1

where

$m_{d r y, u}=\frac{m_{o, u}}{1+w_{p}}$

$m_{o, u}$ is the mass of the whole unit prior to drying, (g);

$w_{p}$ is the moisture content of a group of three representative portions of a whole unit specimen; and

$V_{n, u}$ is the net volume of unit, $\left(\mathrm{mm}^{3}\right)$

\section{3-3. Compressive strength test}

The compressive strengths of the masonry units were measured for the ancient clay bricks, stone and modern clay specimens corresponding to EN 772-1 [19]. Ten specimens were tested for each case to determine mean values of compressive strength using a digitally controlled compression machine with a maximum load capacity of $2000 \mathrm{kN}$. The testing machine was calibrated so that the maximum permissible mean error of forces as personage of indicated force did not exceed \pm 2 as per in the standards. A constant loading rate of $1.5 \mathrm{kN} / \mathrm{s}$ was used throughout the tests. Load was monitored until 
specimen failure and the maximum load in $\mathrm{kN}$ was recorded. The specimens were tested under the immersion condition for a period of $24 \mathrm{~h}$ and subsequently allow them to drain for 15 minutes in still air. A capping technique was followed in order to achieve samples with adequate plane tolerance before performing the test.

\section{3-4. Initial rate of water absorption test}

This test was performed according to the EN 772-11 [20]. The samples were immersed in a tray with dimensions of $800 \times 800 \times 20 \mathrm{~mm}(/ \times w \times t)$. The depth of the water was normally $5 \mathrm{~mm} \pm 1 \mathrm{~mm}$ and increased for samples with irregular face so that it just contact with the water surface. A scale with accuracy of $0.01 \mathrm{~g}$ was used to measure the loss in mass after drying for $70{ }^{\circ} \mathrm{C} \pm 5{ }^{\circ} \mathrm{C}$ and $100 \pm 5{ }^{\circ} \mathrm{C}$ for stone and clay samples respectively. The test was repeated five times each 30 minutes duration and the Initial rates of water absorption for clay brick units and stone specimens were calculated using Equations 2 and 3 respectively:

$$
\begin{aligned}
C_{w, i}=\frac{m_{s o, s}-m_{d r y, s}}{A_{s} t} \times 10^{3} \quad\left[\mathrm{~kg} /\left(\mathrm{m}^{2} \times \min \right)\right] & \text { Eq. } 2 \\
C_{w, s}=\frac{m_{s o, s}-m_{d r y, s}}{A_{s} \sqrt{t_{s o}}} \times 10^{6}\left[\mathrm{~g} /\left(\mathrm{m}^{2} \times \mathrm{s}^{0.5}\right)\right] & \text { Eq. } 3
\end{aligned}
$$

Where

$C_{w, i}$ and $C_{w, s}$ are the initial rate of water absorption for clay masonry units and the coefficient of water absorption due to capillary action for the stone masonry units respectively.

$m_{s o, s}$ is the mass of the specimen in grams after soaking for time $\mathrm{t},(\mathrm{g})$;

$m_{d r y, s}$ is the mass of the specimen after drying, (g);

$A_{S}$ is the gross area of the face of the specimen immersed in water; $\left(\mathrm{mm}^{2}\right)$;

$t_{s o}$ is the time of soaking, (s); and

$t=1$ minute

\section{3-5. Thermal properties}

Thermal conductivity and thermal resistance of the masonry units were determined according to EN 1745:2012 [21]. Model S1 described in [21] was used to calculate the thermal conductivity based upon the values of the net dry densities. Tabulated values for thermal conductivity were adopted using Annex (A) which is equivalent to the properties of the used masonry unit. These tabulated values can be applied for materials where there is a reasonable production control of the net dry density and given as $50 \%$ and $90 \%$ fractiles population. The density of the ancient clay bricks, stone and modern clay specimens under effect of high temperatures was also measured. The latter test was carried out under effect of five different temperatures: $100{ }^{\circ} \mathrm{C}, 200{ }^{\circ} \mathrm{C}, 300{ }^{\circ} \mathrm{C}, 400{ }^{\circ} \mathrm{C}$ and $500{ }^{\circ} \mathrm{C}$ for a period of two hours at each temperature level. 


\section{Results and discussion}

\section{4-1. Dimensions and flatness}

The dimensions of both ancient brick configurations as well as modern clay brick units and stone samples are presented in Figures 9- 11.

It can be seen that the nominal dimension for the wide ancient brick units were $30 \mathrm{~cm}, 30 \mathrm{~cm}$ and $7 \mathrm{~cm}$ $(I, w$ and $t)$ respectively, as shown in Figure 9 . The corresponding values for the narrow ancient brick samples are $30 \mathrm{~cm}, 15 \mathrm{~cm}$ and $7 \mathrm{~cm}$ respectively. On another hand, the nominal dimensions of the modern clay brick units were $24 \mathrm{~cm}, 11 \mathrm{~cm}$ and $8 \mathrm{~cm}$ respectively, as shown in Figure 10. Approximately similar nominal dimensions were observed for the stone specimens with $10 \mathrm{~cm}$ for each of length, width and height, as shown in Figure 11.

In terms of deviation from the mean dimension, Figure 9 shows that sample number 3 showed the highest variation in length, width and height with ratios of $+4.1 \%,+3.7 \%$ and $-11.9 \%$ respectively for the wide ancient brick units. This indicative for the action of overpressure subjected upon this sample which reduces the height of brick, consequently increasing both length and width dimensions of the unit. The maximum deviation in length and width for the narrow ancient bricks were observed at sample number 1 , whereas sample number 4 showed the maximum deviation from the mean value of the height dimension. The former values of deviations were $-9.6 \%,-6.2 \%$ and $+12.2 \%$ respectively. This is may be due to the variations in the dimensions of the mould used in the productions of these units.

The deviation from the mean value of length, width and height dimensions for modern clay brick units were $+1 \%,-2 \%$ and $+1.5 \%$ at sample numbers 8,6 and 3 respectively, as shown in Figure 10 . The corresponding values for the stone specimens were $-10.7 \%,-9.2 \%$ and $-15 \%$ at samples number 7,1 and 4 respectively, as shown in Figure 11. It should be noted that the modern clay units were produced using shredder plate, while stone samples were fabricated using a precision automatic mechanical cutter.

Comparing with the EN 771-1 [22], the tolerance on the mean value $(T)$ and range of dimensions $(R)$ for the tested samples should be within the range of Equations 4 and 5 respectively.

$T=\mp 0.4 \sqrt{(\text { work size dimension) }} \quad \mathrm{mm}$ or $3 \mathrm{~mm}$ (whichever is greater) Eq. 4

$R=0.6 \sqrt{(\text { work size dimension })} \quad \mathrm{mm} \quad$ Eq. 5

According to the above equations, the calculated and measured tolerance on the mean value and range of dimensions for the tested samples are presented in Table 2.

It can be seen from Table 2 that neither wide nor narrow ancient bricks units satisfied the tolerance and range requirements of dimensions as stipulated in EN 771-1 [22]. This may be attributed to the differential volume changes during the burning process resulting from the poor process control, the use of poor quality mould and aging effects. However, EN 771-1 [22] referred that the deviation in dimensions could be declared by the manufacturer (may be wider than that specified in Eqs. 4 and 5). 
On this basis, a suitable formula was derived to calculated the tolerance in dimensions for the ancient brick units as per in Eq. 6.

$T=\mp 1.2 \sqrt{(\text { work size dimension })} \mathrm{mm}$

Eq. 6

According to the classification of EN 6073: Part 1 [23], the wide ancient samples considered to be block units because their width exceeds $225 \mathrm{~mm}$. This allows construction of a thick wall leaf with one wide unit, as shown in Figure 6. Consequently, the resulting double-leaf or composite walls can be easy constructed. Such attitude may explain emphasise of the old builders to reconcile between the widths of both unit and wall leaf.

With regard to unit flatness, the mean length of the diagonal and the maximum concave and convex values from the bed face of the masonry units are shown in Table 3.

From Table 3, it can be seen that the modern clay brick units have the minimal values of convex and concave irregularity, whilst both ancient brick types and the stone samples showed reasonable variation from the bed surface of the masonry units. This feature may permit for use of the former units with thin layer mortar.

\section{4-2. Density}

Figure 12 shows the results obtained for the density measurements. It can be seen that both types of ancient brick configurations exhibited lower average densities than modern clay brick and stone specimens. There are several factors which are thought to this experimental outcome. These are the pressing method used in removing the confined air, the higher degree of temperatures adopted during the burning of the brick and the use of a longer period of firing.

In general, both of the ancient configuration bricks units showed similar value of density with variation not exceeding $2.25 \%$ of the average results. This indicative for the high quality control in manufacturing the ancient bricks. The maximum and minimum observe densities were at sample numbers 5 and 9 for the wide ancient brick units with values of $1809 \mathrm{~kg} / \mathrm{m}^{3}$ and $1337 \mathrm{~kg} / \mathrm{m}^{3}$ respectively. The corresponding numbers of samples for the narrow ancient brick units were at 3 and 2 with values of $1619 \mathrm{~kg} / \mathrm{m}^{3}$ and $1267 \mathrm{~kg} / \mathrm{m}^{3}$ respectively. These results are consistent with the measured dimensions for these samples. For the same weight, the highest volume sample is associated with the lowest value of the density and vice versa. Moreover, the microstructure of the ancient brick units and the connection of their interior pores may have the role in producing the specified level of density [9].

For the results obtained for the modern clay brick units, it can be seen that sample number 3 shows the highest value of density reaching $1800 \mathrm{~kg} / \mathrm{m}^{3}$, whereas sample number 4 gives the lowest value of density at $1516 \mathrm{~kg} / \mathrm{m}^{3}$. The corresponding results for stone specimens were $2524 \mathrm{~kg} / \mathrm{m}^{3}$ and $1927 \mathrm{~kg} / \mathrm{m}^{3}$ at sample numbers 9 and 8 respectively. Volumes of the modern brick units were calculated as a net volume as suggested by EN 772-13 [18].

Comparing with EN 772-1 [22] specifications, both of the ancient configuration brick units in addition to modern clay brick and stone specimens exceeded the tolerance requirements of density for category 2 (a maximum permitted variation in density is $10 \%$ ). The maximum values of deviation for the 
aforementioned samples were $16.7 \%, 15.5 \%, 11.7 \%$ and 14.2 respectively. However, the former standards mention that wider category tolerance may be adopted by the manufacturer.

Based upon density measurements, the application of the ancient brick units can be deduced which is essentially as for loading and thermal insulation purposes [22] and are in agreement with the classification of HD units. The latter units usually used in unprotected masonry against water penetration. This explains why such ancient brick units maintain their integrity along this period of time even with the aggressive weathering such as would be experienced at Nippur.

\section{4-3. Compressive Strength}

Figure 13 shows the compressive strength test results for both ancient brick configurations, modern brick and stone samples.

It can be seen that the stone samples exhibited higher compressive strength than both ancient and modern brick units with a value $17 \mathrm{MPa}$. This behaviour relates to the high strength of the raw rocks and is consistent with both composition and structure of the rock [24]. The values of compressive strength of both ancient brick configurations were higher than that of modern brick units. They revealed average compressive strength of $14.9 \mathrm{MPa}$ and $14.4 \mathrm{MPa}$ respectively with a minimal variation in each individual reading. The higher strength level of the ancient brick units can be explained by serious conditions of compression and firing during the manufacture process of the unit. These combined to produce higher cohesive unit under action of the applied loads.

According to EN 771-1 [22], no limit has been specified to the value of compressive strength of the masonry unit. Rather, it was only restricted by the declaration of the manufacturer for normalised compressive strength. However, Iraqi Standard No. 25 [25] involved three categories of brick units which are designated $\mathrm{A}, \mathrm{B}$ and $\mathrm{C}$ with stipulated minimum average compressive strengths for categories of 18 $\mathrm{MPa}, 13 \mathrm{MPa}$ and $9 \mathrm{MPa}$ respectively. Masonry units of category A are used for load bearing walls exposed to the moisture effect and category $\mathrm{B}$ units are used for the load bearing walls protected from moisture exposure, whilst category $C$ refers to the masonry units used in the main portion of walls. According to the Iraqi Standard No. 25 [25], both ancient configuration bricks are classified as category $\mathrm{B}$, whilst modern clay brick units classify as category $\mathrm{C}$.

Eurocode 6 [26] suggested the following formula to predict the compressive strength of the masonry walls from its components:

$f_{k}=K f_{b}^{0.7} f_{m}^{0.3}$

Eq. 7

where $\mathrm{f}_{\mathrm{k}}$ is the characteristic compressive strength of masonry walls, in MPa; $\mathrm{K}$ is a constant depending on the types of unit and mortar being used, falling within the range of 0.4-0.6; the corresponding value of $\mathrm{K}$ for using a solid masonry unit and general purpose mortar is 0.55 [26]. $\mathrm{f}_{\mathrm{b}}$ and $\mathrm{f}_{\mathrm{m}}$ are the normalised mean strength of the unit and mortar in the direction of the applied action.

In order to generalise Equation 7 for use with different masonry unit geometries, EN 772-1 [27] incorporates the shape factor $\delta$. If cement mortar with compressive strength value of $12 \mathrm{MPa}$ is used and applying Equation 7, the predicted characteristic compressive strengths for the masonry walls constructed with units of stone, ancient brick and modern brick samples are 8.4 MPa, 7.6 $\mathrm{MPa}$ and 5.9 MPa respectively. 
ACl 530-11 [28] suggested tabulated values to predict the characteristic compressive strength values of masonry walls which mainly depends on the strength level of the unit and the type of mortar used ( $\mathrm{S}$ or $\mathrm{N})$. The designation of $\mathrm{S}$ or $\mathrm{N}$ mortar refers to a mortar with a minimum compressive strength value of 12.4 $\mathrm{MPa}$ and 5.16 $\mathrm{MPa}$ at 28-day age respectively. No equivalent values are found to the results of compressive strength of tested units in this study. However, if a linear interpolation feature is permitted, only the masonry walls constructed with stone and ancient brick units can be determined at $8.5 \mathrm{MPa}$ and $7.85 \mathrm{MPa}$ respectively. The former calculated compressive strength values are in closed agreement with those predicted using the suggested formula of Eurocode 6 [26] (Eq.7).

\section{4-4. Initial rate of water absorption}

The results obtained for the initial rate of water absorption tests of ancient brick configurations, modern clay brick units in addition to the coefficient of water absorption for the stone sample are shown in Figure 14.

It can be seen that the initial rate of water absorption increases with an increase in the soaking time for both ancient and modern brick samples. This behaviour is thought to be due to the role of capillary pores which tend to increase the penetration of water into samples. However, the initial rate of water absorption showed a decrease after a soaking period of $90 \mathrm{~min}$ for the narrow ancient and modern brick samples due to the saturated state being reached. No further increase in the amount of absorbed water is observed and hence the influence of the capillary pores will be diminished. The similar behaviour of initial rate of water absorption for both ancient brick samples and modern brick units may be attributed to the use approximately identical clay material which is still readily available at the southern parts of Iraq [8].

In contrast to both ancient and modern bricks, the stone specimens showed a decrease in the value of coefficient of water absorption with an increase in the immersed time. This was to be expected, as the capillary action decreases with time.

The measured values of total absorption for wide ancient, narrow ancient, modern bricks and stone samples after submerged for $24 \mathrm{~h}$ were $2.6 \%, 2.75 \%, 10.4 \%$ and $2.8 \%$ respectively. All of these values are lower than the specified limit for category A (20\%) designated by the Iraqi Standard No. 25 [25]. Based upon the aforementioned results, it can be noted the superior performance of both ancient brick units in preventing more water absorption to the interior body of the unit.

\section{4-5 Thermal properties}

The results obtained of thermal conductivity for the three types of masonry units are shown in Figure 15.

In general, it can be seen that the values of thermal conductively for ancient bricks were lower that of both modern clay brick and stone samples. This behaviour can be attributed to two factors. The first is the higher level of temperature adopted in manufacturing the ancient bricks which leads to removal of the confined chemically combined waters within the pore structure of the unit and thermal conductivity of the water is higher than that for air, so the resulting value of thermal conductivity will reduced. The 
second is transferring the clay material to surfaces of glass crystals associated with reduction in value of thermal conductivity. This technique was explored by ancient builders in producing a lightweight brick unit [3]. However, the differences between the values of thermal conductivity of the ancient and modern clay brick samples may be considered a minimal.

The values of thermal resistances of the masonry walls produced from different units can be determined from the following equations [21].

$$
\begin{aligned}
& R_{\text {design,mass }}=\frac{d}{\lambda_{\text {design,mass }}} \\
& \lambda_{\text {design,mass }}=a_{\text {mor }} \lambda_{\text {design,mor }}+a_{\text {unit }} \lambda_{\text {design,unit }}
\end{aligned}
$$

Where

$R_{\text {design,mass }}$ is the thermal resistances of the masonry wall $\left(\mathrm{m}^{2} \mathrm{~K} / \mathrm{W}\right)$;

$d$ is the thickness of the masonry $(\mathrm{m})$;

$\lambda_{\text {design,mass }}$ is the design thermal conductivity value of the masonry wall $(\mathrm{W} / \mathrm{mK})$;

$a_{m o r}$ is the percentage area of the joint;

$\lambda_{\text {design,mor }}$ is the design equivalent thermal conductivity of the mortar joint $(\mathrm{W} / \mathrm{mK})$;

$a_{\text {unit }}$ is the percentage area of the unit;

$\lambda_{\text {design,unit }}$ is the design thermal conductivity of the unit $(\mathrm{W} / \mathrm{mK})$.

Using tabulated value for the cement mortar with density of $1800 \mathrm{~kg} / \mathrm{m}^{3}$ which usually adopted to build the walls of modern clay bricks and stones in addition to the suggested value for the bitumen material used with ancient walls, the values of thermal conductivities are $0.82 \mathrm{~W} / \mathrm{mK}$ and $0.17 \mathrm{~W} / \mathrm{mK}$ respectively [21 and 29]. Applying Eq. 8 with 30\% percentage area of the mortar, the thermal resistances of the ancient brick, modern brick and stone masonry walls per $100 \mathrm{~mm}$ thick are $0.3 \mathrm{~m}^{2} \mathrm{~K} / \mathrm{W}, 0.16 \mathrm{~m}^{2} \mathrm{~K} / \mathrm{W}$ and $0.053 \mathrm{~m}^{2} \mathrm{~K} / \mathrm{W}$ respectively. Previous calculations of thermal resistance with other possible examples for masonry construction with different types of mortar are presented in Table 4. It can be seen that the highest thermal resistance is corresponding to the masonry walls formulated using ancient brick units and both bitumen and gypsum mortars due to their lower values of thermal conductivity. On the other hand, all of the masonry walls consist of stone units with different bonded mortars exhibited lower thermal resistance as the value of thermal conductivity of stone units is extremely high $(2.3 \mathrm{~W} / \mathrm{mK})$.

\section{5-6 Density at high temperatures}

The results of density measurements at elevated temperatures for the different unit samples are illustrated in Figure 16.

In general, there was a trend of decreasing density of all tested samples with an increase in temperature. This behaviour is due to the elimination of the free water from the capillary pores by evaporation, in addition to the loss of chemically bound water [30-32]. The decrease in density at $600{ }^{\circ} \mathrm{C}$ compared to that at $100{ }^{\circ} \mathrm{C}$ temperature were about $20 \%$ for both ancient brick configurations and $5 \%$ for both modern clay brick and stone samples. The former behaviour shows the moisture equilibrium for both modern clay brick and stone samples in contrast with the ancient brick units. This may be due to 
the long period of environmental action which leads to absorb more moisture from the atmosphere. A clear decrease in the density value at temperature level of $300{ }^{\circ} \mathrm{C}$ was noted. This may be explained by the phase change in the hydrated calcium silicate crystals at this temperature [31].

Visual inspection of the modern clay brick samples revealed the occurrence of some cracking at higher temperatures. Conversely, little cracking was noted in both ancient configuration and stone samples at high temperatures. It seems likely that this behaviour is due to the large temperature variation between the outer and inner surfaces of modern clay brick units, associated with a faster heating rate. These factors combined to produce a higher internal pressure exceeding the tensile strength of the brick sample [33-35]. A colour change from white to pink was also observed for all tested samples at elevated temperatures.

According to EN 13501-1 [36], all of the tested samples classify as Class A1 where no sustained flaming has been observed during the test, so there is no need for additional protection when these products are exposed to the fire. The same cannot be said in case of ancient masonry walls which include bitumen mortar where a sustained flame will occur when this type of mortar is exposed to fire. Therefore, one or more layers of a protective material should be applied into these walls in order to inhibit fire damage.

\section{Conclusions}

This study was carried out to evaluate the construction techniques adopted at ancient Nippur city. This was by two approaches site investigations and experimental measurements for the brick units used in construction. The experimental results have been compared with modern brick units available in Iraq and with natural stone samples.

The explorations of the site showed that the significant buildings were constructed using fired brick units of two sizes, namely $(30 \times 30 \times 7) \mathrm{cm}$ and $(30 \times 15 \times 7) \mathrm{cm}$. The concept of composite walls was applied combined with the strategy of working design technique. Bitumen material was used as binder to both provide adhesion and achieve the necessary strength for the masonry, and to increase the thermal resistance feature. The equilibrium status was followed to fulfill a wall opening of about 1-1.5 $\mathrm{m}$ width at the King's chamber without the use of a lintel or beams by means of grading in construction and getting a coinciding between the trust line and the orientation of inclined upper part of opening. The construction of the secondary staircase was found to be in an advanced architectural style for the time due to its unique geometry.

The experimental results obtained show that both ancient brick configurations and stone samples did not satisfy the tolerance and range of dimensions requirements suggested by EN 771-1 [22]. Based on the results obtained, an appropriate formula was suggested to determine the dimensional tolerance of the ancient brick samples. Lower density values were recorded for the ancient bricks compared with both modern clay bricks and stone specimens due to the firing processes used in the manufacture of the ancient bricks. Similar values of compressive strength were observed for both ancient brick and natural stone samples, reaching about $17 \mathrm{MPa}$. This is satisfies the requirements of load bearing applications, whilst modern clay brick samples exhibit lower compressive strength value suitable for application to 
interior walls. Applying Eq.7 suggested by Eurocode 6 [26], the highest characteristic compressive strength was for the wall constructed with stone units followed by the wall of the ancient clay bricks and then by the wall of modern bricks. For the ancient and modern brick samples, the initial rate of water absorption increases with an increase of the soaking time, but tends to decrease after $90 \mathrm{~min}$. Superior thermal conductivity, thermal resistance and durability under fire action were observed for the ancient brick samples compared with modern clay brick and stone samples.

\section{Acknowledgements}

The authors would like to thank the archaeological office in Qadisiyiah Governorate for permission to work in ancient Nippur city. The technical assistance of the laboratory staff at the University of AlQadisiyiah is greatly appreciated. Many thanks for the efforts provided by Amjed Enad, Raad Enad, Mohamed Emad and Asaad Razaq.

\section{References}

[1] Donald E. McCown, Excavations at Nippur, 1948-50, Journal of Near Eastern Studies, vol. 11, no. 3, pp. 169-176, 1952.

[2] Amer Najeem, The city of Nippur, Journal of archaeological, vol. 5, pp. 1-3, 2012.

[3] Drysdale R. G. and Hamid A. A. Masonry structures behavior and design. The Masonry Society, 3rd edition, 2008.

[4] McGuire Gibson (Oriental Institute, U. of Chicago) 'Patterns of occupation at Nippur, 1992.

[5] V.E. Crawford, Nippur the Holy City, Archaeology, vol. 12, pp. 74-83, 1959.

[6] McGuire Gibson, Excavation Nippur Eleventh Season, 1948-50, the Oriental Institute of The University of Chicago, Oriental Institute Communications No.22, 1975.

[7] T. Fish, The Summerian City Nippur in the Period of the Third Dynasty of Ur, Iraq, vol. 5, pp. 157-179, 1938.

[8] Dan, M. B., Přikryl, R., \& Török, Á. Materials, Technologies and Practice in Historic Heritage Structures. Berlin, Germany: Springer, 2014.

[9] Stefanidou, M., Papayianni, I., \& Pachta, V. Analysis and characterization of Roman and Byzantine fired bricks from Greece. Materials and Structures, 2015; 48(7): 2251-2260.

[10] Hussain, A., Akhtar, S. Review of Non-Destructive Tests for Evaluation of Historic Masonry and Concrete Structures, Arab J Sci Eng, 2017; 42:925-940.

[11] McGuire Gibson and et al., Excavations at Nippur Twelfth Season, the Oriental Institute of the University of Chicago, Oriental Institute Communications No.23, 1978.

[12] Augusta McMahon, Nippur V the Early Dynastic to Acadian Transition the Area WF Sounding at Nippur, the Oriental Institute of the University of Chicago, 1984.

[13] Donald E. McCown and et al., Nippur II the North Temple and Sounding E, the Oriental Institute of the University of Chicago, vol. XCVII, 1978. 
[14] Al-Taie E., Al-Ansari N., Knutsson S., Effect of Bearing Capacity on Designing Foundations in Iraq Using STAAD Pro-v8i. Engineering, 2014; 6: 292-303.

[15] Al-Sibahy A., Edwards R. Behaviour of masonry wallettes made from a new concrete formulation under compression loads of at ambient temperatures: Testing and modelling. Construction and Building Materials, 2014; 63: 271-280.

[16] EN 772-16. Methods of test for masonry units, Part 16: Determination of dimensions. British Standards; 2011.

[17] EN 772-20. Methods of test for masonry units, Part 20: Determination of flatness of faces of masonry units. British Standards; 2000.

[18] EN 772-13. Methods of test for masonry units, Part 20: Determination of net and gross dry density of masonry units (except for natural stone). British Standards; 2000.

[19] EN 772-1. Methods of test for masonry units: Part 1: Determination of compressive strength. British Standards, 2000.

[20] EN 772-11. Methods of test for masonry units, Part 20: Determination of water absorption of aggregate concrete, autoclaved aerated concrete, manufactured stone and natural stone masonry units due to capillary action and the initial rate of water absorption of clay masonry units. British Standards; 2011.

[21] EN 1745. Masonry and masonry products: Methods for determining thermal properties. British Standards; 2012.

[22] EN 771-1. Specification for masonry units - Part 1: Clay masonry units. British Standards; 2011.

[23] EN 6073-1. Precast concrete masonry units: Part 1: Specification for precast of concrete masonry units. British Standards, 1981.

[24] Neville, A.(2000) Properties of concrete, Pearson Education Limited, Edinburgh: England 1-842.

[25] I.Q.S No. 25. Clay Building Bricks. The Iraqi Standards, 1988.

[26] EN 1996-1-1 Eurocode 6. Design of masonry structures: Part 1-1: Common rules for reinforced and unreinforced masonry structures. British Standards, 2005.

[27] EN 772-1. Methods of test for masonry units: Part 1: Determination of compressive strength. British Standards, 2000.

[28] Building Code Requirements for Masonry Structures, ACI 530-11/ASCE 5-11/TMS 402-11. Masonry Standards Joint Committee, 2011

[29] http://www.engineeringtoolbox.com/thermal-conductivity-d 429.html, 2015.

[30] Al-Sibahy A. Improvement of gypsum behaviour using glass wool. Babylon Journal for Sciences, In Press, 2016

[31] Hertz KD. Concrete strength for fire safety design. Magazine of Concrete Researches, 2005; 25(8):445-53.

[32] Formosa J., Chimenos JM, Lacasta AM, Haurie L, Rosell JR. Novel fire-protecting mortars formulated with magnesium by-products. Cement and Concrete Researches, 2011; 41:191-6.

[33] Ali F., Nadjai A, Choi S. Numerical and experimental investigation of the behaviour of high strength concrete columns in fire. Engineering Structures, 2010;32:1236-43.

[34] Borhan T. M. and Bailey C. G., Modelling basalt fibre reinforced glass concrete slabs at ambient and elevated temperatures. Materials and Structures, 2013; 1-11.

[35] Peng G-F, Bian SH, Guo ZQ, Zhao J, Peng XL, Jiang YC. Effect of thermal shock due to rapid cooling on residual mechanical properties of fiber concrete exposed to high temperatures. Construction and Building Materials, 2008;22(5): 948-55.

[36] EN 13501-1. Fire classification of construction products and building elements, Part 1: Classification using data from reaction to fire tests. British Standards, 2009. 


\section{List of Tables}

Table 1: Calculated vertical transmission dead loads from the top of King's chamber to the base of Ziggurat

Table 2: Calculated and measured values of $T$ and $R$

Table 3: Mean length of the diagonal and the maximum concave and convex values

Table 4: Thermal resistance $(R)$ for possible examples of masonry walls construction with different types of mortar

\section{List of Figures}

Figure 1: Site of the ancient Nippur city; (a) general site, (b) the Ekur Ziggurat

Figure 2: Details of the Ekur Ziggurat from [2]

Figure 3: Details of the King's Chamber and roof of the Ekur Ziggurat; (a) grading technique used in King's chamber openings, (b) construction roofs of Ekur Ziggurat

Figure 4: Composite wall construction as used in the ancient Ekur Ziggurat at Nippur

Figure 5: External view of the masonry bond used in the ancient walls of Nippur city

Figure 6: Details of the bond used in composite walls with the method of leafs connections

Figure 7: Bitumen material used as a binder in construction of walls at ancient Nippur city

Figure 8: The secondary staircase constructed at Ekur Ziggurat

Figure 9: Dimensions the ancient clay brick; (l= length), ( $w=w i d t h)$ and ( $h=$ height).

Figure 10: Dimensions of the modern clay brick samples; (l= length), ( $w=$ width) and $(h=h e i g h t)$.

Figure 11: Dimensions of the stone samples; (l= length), ( $w=$ width) and ( $h=$ height).

Figure 12: The measured density values for both ancient, modern clay brick and stone specimens

Figure 13: The measured value of compressive strength values for various tested samples

Figure 14: Initial surface absorption at various soaking time for different tested samples

Figure 15: Calculated thermal conductivity for various unit samples

Figure 16: Density of various unit samples at different temperature exposure 
Table 1: Calculated vertical transmission dead loads from the top of King's chamber to the base of Ziggurat

\begin{tabular}{|c|c|c|c|c|c|c|c|}
\hline \multirow[b]{2}{*}{ Level } & \multicolumn{3}{|c|}{ Dimensions (m) } & \multirow{2}{*}{$\begin{array}{c}\text { Volume of } \\
\text { the level }(\mathrm{V}) \\
\left(\mathrm{m}^{3}\right)\end{array}$} & \multirow{2}{*}{$\begin{array}{c}\text { Type of } \\
\text { Material filled }\end{array}$} & \multirow{2}{*}{$\begin{array}{c}\text { Density of } \\
\text { material }(\gamma) \\
\left(\mathrm{kN} / \mathrm{m}^{3}\right)\end{array}$} & \multirow{2}{*}{$\begin{array}{c}\text { Vertical load of } \\
\text { the level }(\mathrm{kN}) \\
\quad=V^{*} \gamma\end{array}$} \\
\hline & Length & Width & Height & & & & \\
\hline Level-1 & 60 & 40 & 4 & 9600 & Clay soil & 14.4 & 138240 \\
\hline Level-2 & 53.15 & 34 & 2 & 3614.2 & Clay soil & 14.4 & 52044 \\
\hline Level-3 & 45.15 & 28 & 2 & 2528.4 & Clay soil & 14.4 & 36408 \\
\hline Level-4 & 37.15 & 22 & 2 & 1634.6 & Clay soil & 14.4 & 23538 \\
\hline Level-5 & 29.15 & 16 & 2 & 932.8 & Clay soil & 14.4 & 13431 \\
\hline Level-6 & \multicolumn{2}{|c|}{22.77} & 3 & 68.31 & $\begin{array}{c}\text { Ancient clay } \\
\text { bricks }\end{array}$ & 15.25 & 1041 \\
\hline & & & & & & & Sum $=264705 \mathrm{kN}$ \\
\hline
\end{tabular}


Table 2: Calculated and measured values of $T$ and $R$

\begin{tabular}{|c|c|c|c|c|c|}
\hline & & Wide ancient bricks & Narrow ancient bricks & Modern bricks & Stone samples \\
\hline \multirow{3}{*}{$\begin{array}{l}\text { (T) calculated } \\
\text { from Eq. }(4) \\
(\mathrm{mm})\end{array}$} & $w$ & \pm 7 & \pm 4.9 & \pm 6.2 & \pm 8 \\
\hline & 1 & \pm 7 & \pm 7 & \pm 4.4 & \pm 5.65 \\
\hline & $h$ & \pm 3.4 & \pm 3.4 & \pm 3.5 & \pm 5.7 \\
\hline \multirow{3}{*}{$\begin{array}{c}(\mathrm{T}) \text { measured } \\
(\mathrm{mm})\end{array}$} & $w$ & +11.2 & -14.5 & -2.3 & -10.7 \\
\hline & 1 & +12.4 & -18.7 & +1.7 & -9.2 \\
\hline & $h$ & -8.3 & +8.5 & +1.2 & -1.5 \\
\hline \multirow{3}{*}{$\begin{array}{l}\text { (R) calculated } \\
\text { from Eq. }(5) \\
(\mathrm{mm})\end{array}$} & $w$ & 10.4 & 10.4 & 9.4 & 12 \\
\hline & I & 10.4 & 7.35 & 6.6 & 8.5 \\
\hline & $h$ & 5.1 & 5.1 & 5.3 & 8.5 \\
\hline \multirow{3}{*}{$\begin{array}{c}(\mathrm{R}) \text { measured } \\
(\mathrm{mm})\end{array}$} & $w$ & 22 & 22 & 3 & 10 \\
\hline & 1 & 26 & 35 & 2 & 8 \\
\hline & $h$ & 15 & 11.5 & 4 & 12 \\
\hline
\end{tabular}


Table-3

Click here to download Table: Table-3.docx

Table 3: Mean length of the diagonal and the maximum concave and convex values

\begin{tabular}{|c|c|c|c|c|}
\hline & Wide ancient bricks & Narrow ancient bricks & Modern bricks & Stone samples \\
\hline $\begin{array}{c}\text { Mean length of the } \\
\text { diagonal }(\mathrm{mm})\end{array}$ & 407 & 333 & 260 & 143 \\
\hline $\begin{array}{c}\text { Maximum convex } \\
\text { value }(\mathrm{mm})\end{array}$ & 6 & 4.5 & 0.85 & 3.5 \\
\hline $\begin{array}{c}\text { Maximum concave } \\
\text { value }(\mathrm{mm})\end{array}$ & 5 & 10 & 0.6 & 3.4 \\
\hline
\end{tabular}


Table 4: Thermal resistance $(R)$ for possible examples of masonry walls construction with different types of mortar

\begin{tabular}{|l|c|c|c|c|}
\hline \multirow{2}{*}{ No. } & \multirow{2}{*}{\begin{tabular}{c} 
Type of mortar used \\
\cline { 3 - 4 }
\end{tabular}} & $\begin{array}{c}\text { Ancient brick } \\
\text { units }(\lambda=0.39 \mathrm{~W} / \mathrm{mK})\end{array}$ & $\begin{array}{c}\text { Modern brick } \\
\text { units }(\lambda=0.45 \mathrm{~W} / \mathrm{mK})\end{array}$ & $\begin{array}{c}\text { Stone units } \\
(\lambda=2.3 \mathrm{~W} / \mathrm{mK})\end{array}$ \\
\hline 1 & $\begin{array}{c}\text { Bitumen } \\
(\lambda=0.17 \mathrm{~W} / \mathrm{mK})[25]\end{array}$ & 0.30 & 0.060 \\
\hline 2 & $\begin{array}{c}\text { Cement mortar } \\
(\lambda=0.82 \mathrm{~W} / \mathrm{mK}))[24]\end{array}$ & ---- & 0.16 & 0.054 \\
\hline 3 & $\begin{array}{c}\text { Gypsum mortar } \\
(\lambda=0.17 \mathrm{~W} / \mathrm{mK}))[25]\end{array}$ & 0.30 & 0.27 & 0.060 \\
\hline 4 & $\begin{array}{c}\text { Cement-lime-sand }(1: 0.5: 4.5) \\
\text { mortar }[24](\lambda=0.61 \mathrm{~W} / \mathrm{mK})\end{array}$ & ---- & 0.20 & 0.055 \\
\hline 5 & $\begin{array}{c}\text { Clay mortar })[25] \\
(\lambda=0.95 \mathrm{~W} / \mathrm{mK})\end{array}$ & 0.18 & --052 \\
\hline
\end{tabular}




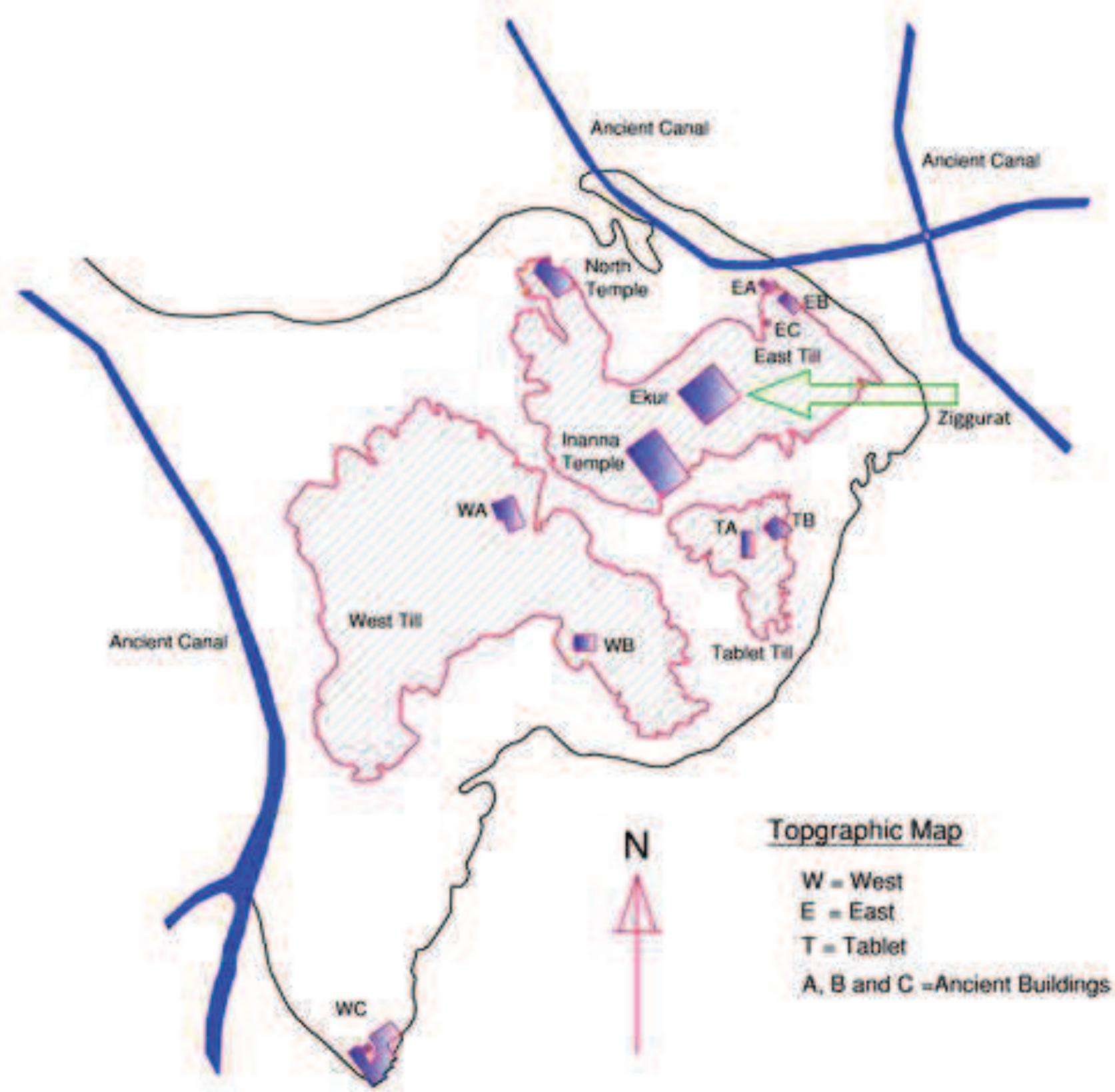




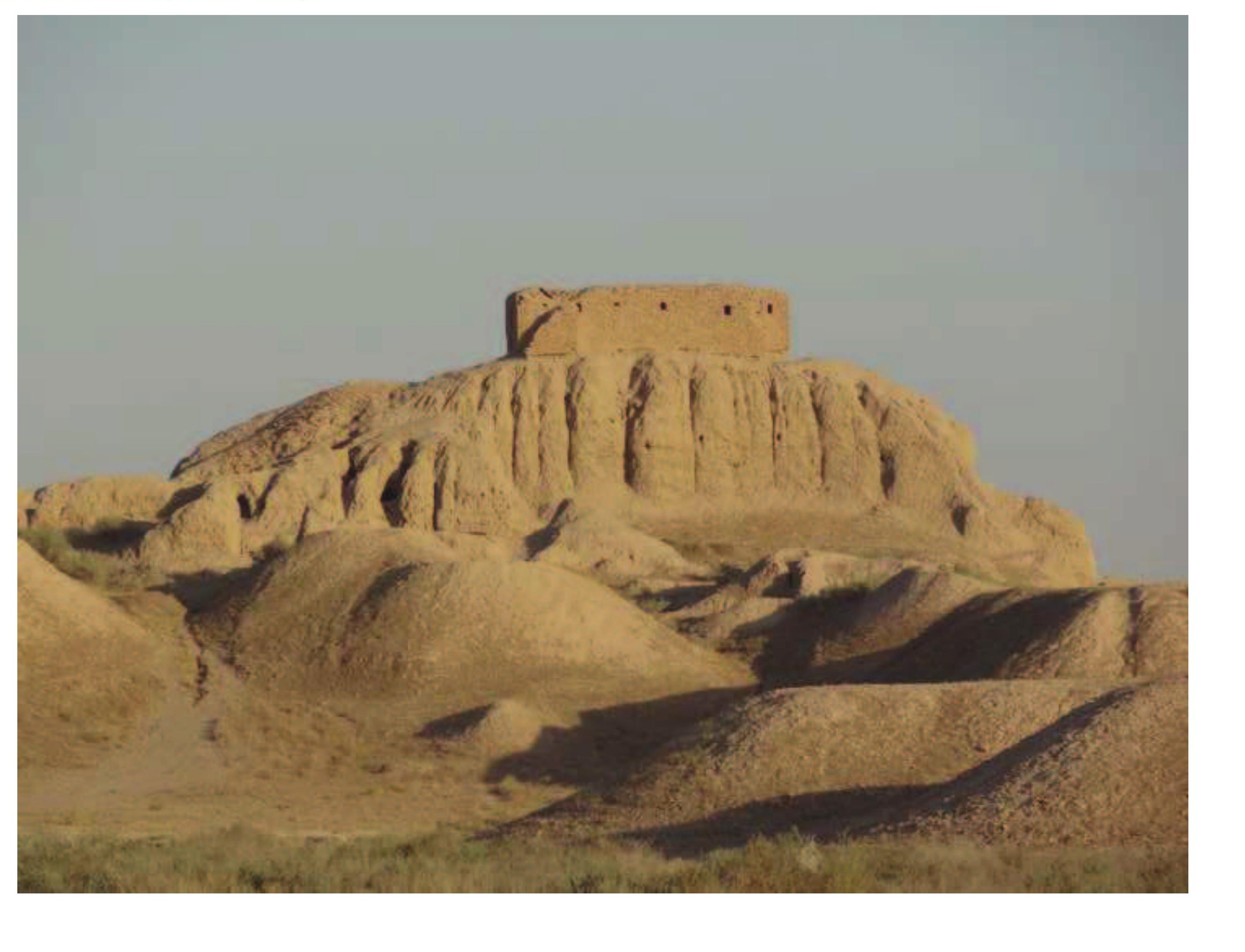

.
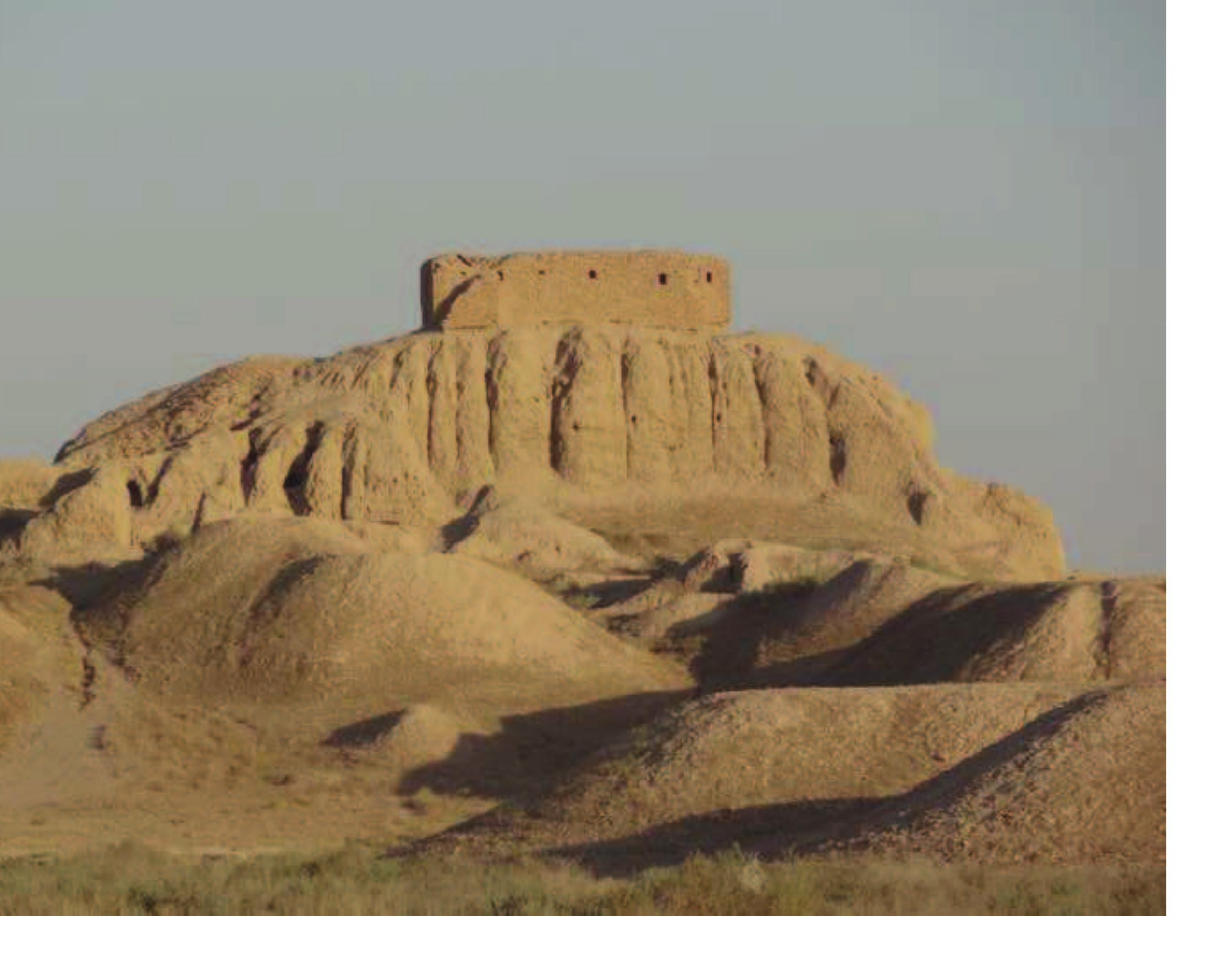
Figure-2
Click here to download high resolution image

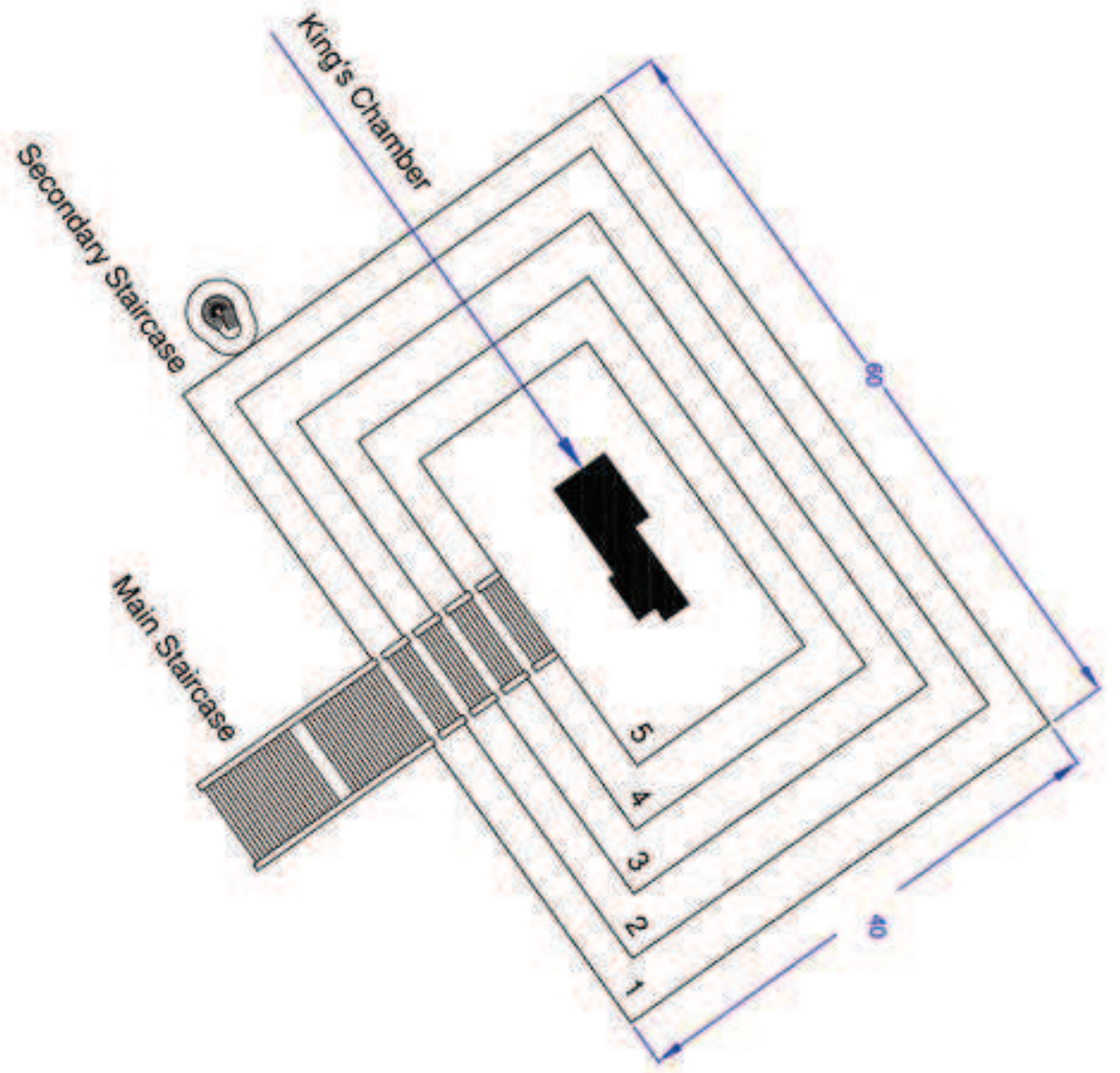



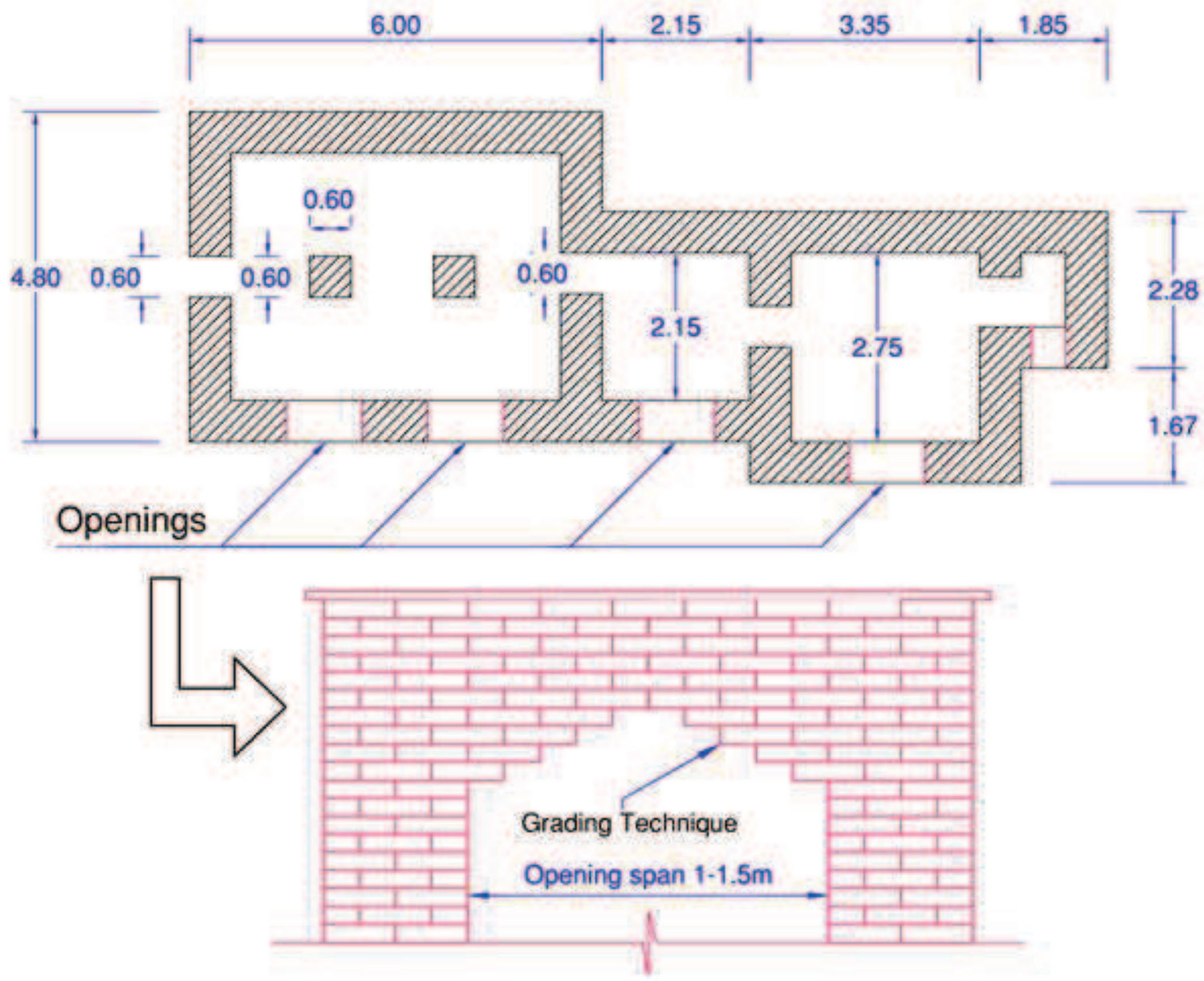
Figure-3-b
Click here

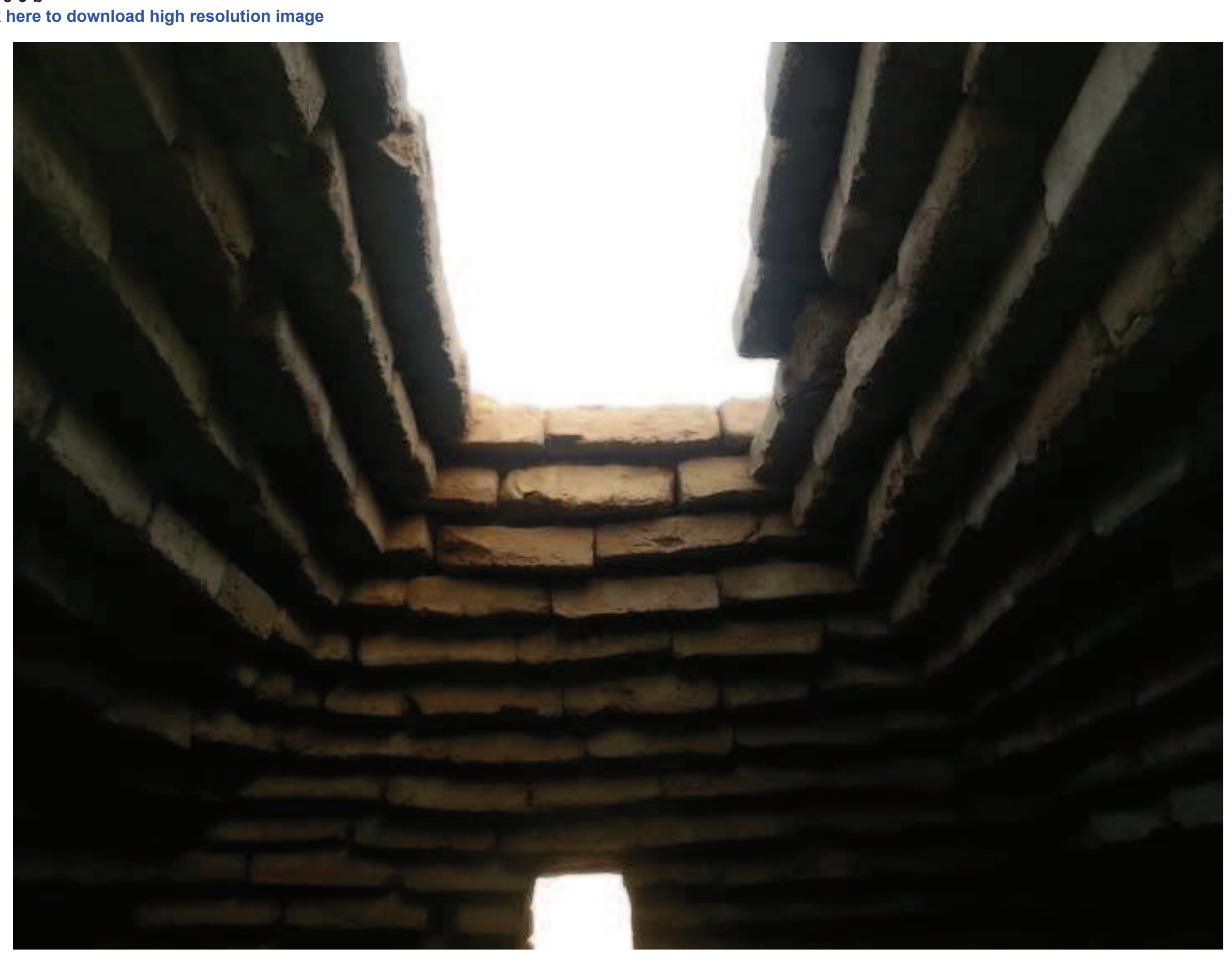

to download high resolution image

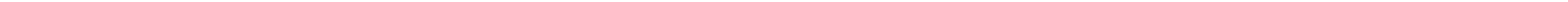

\author{
to to dor
}




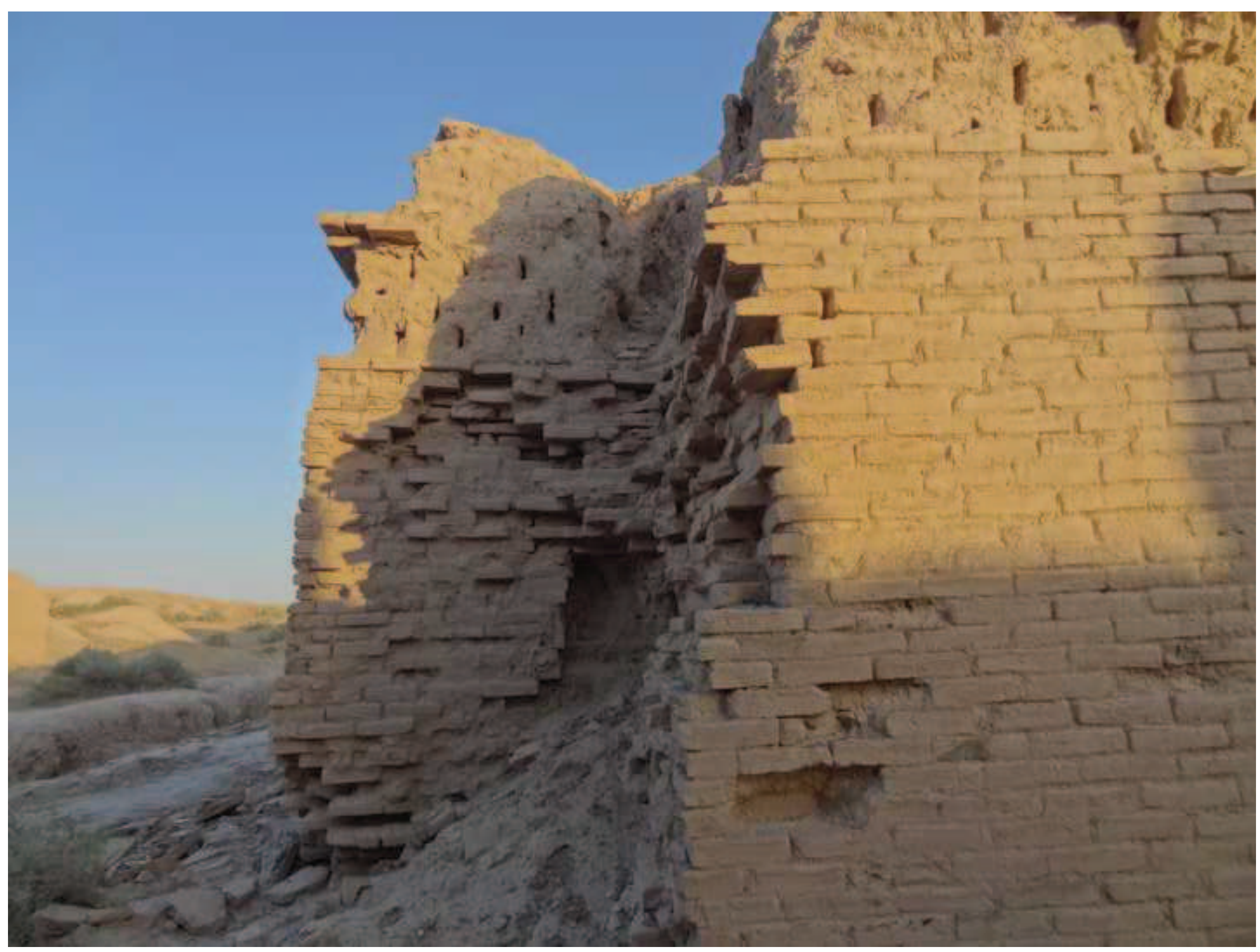


Figure-4-b
Click here to download high resolution image

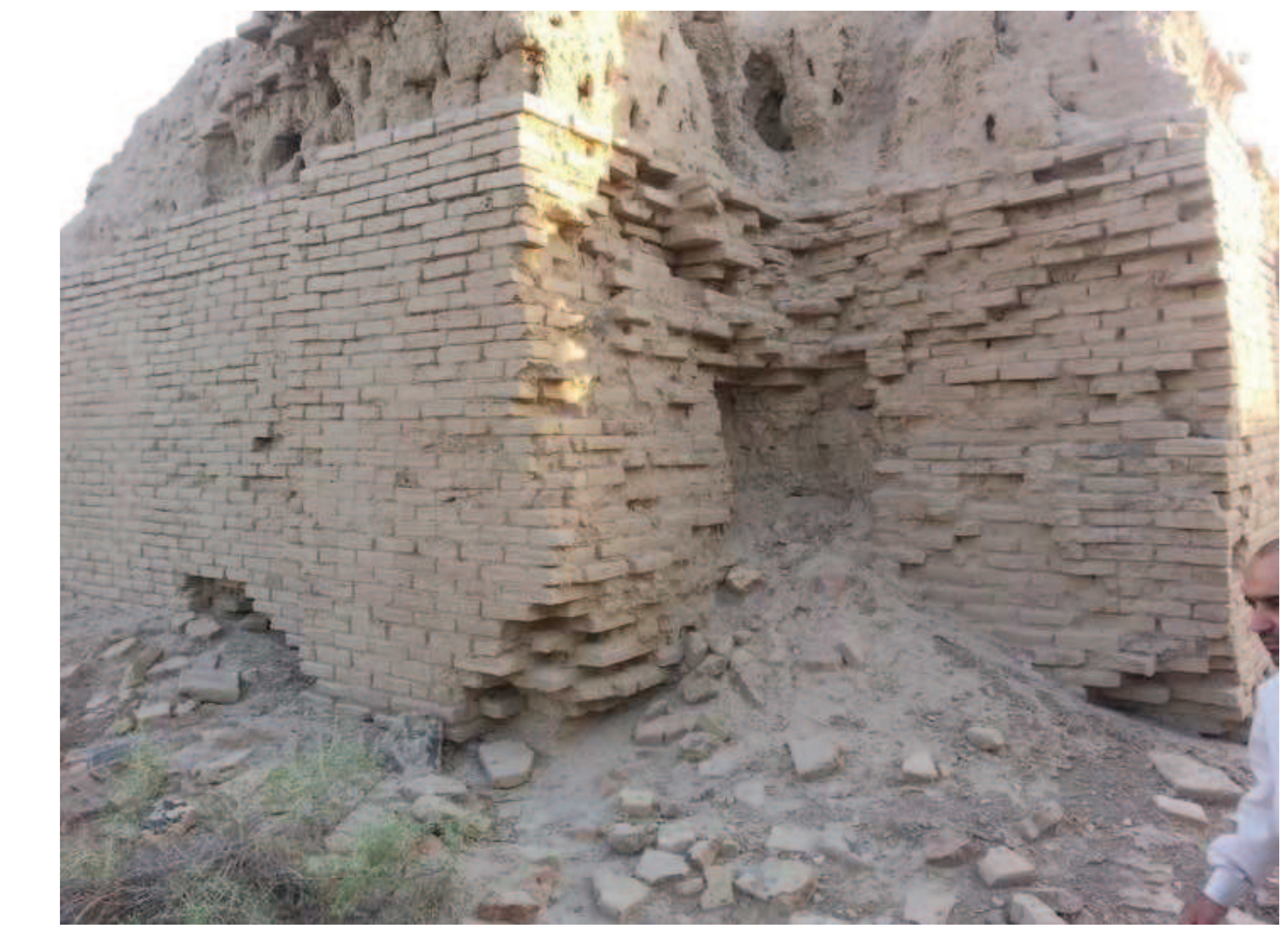




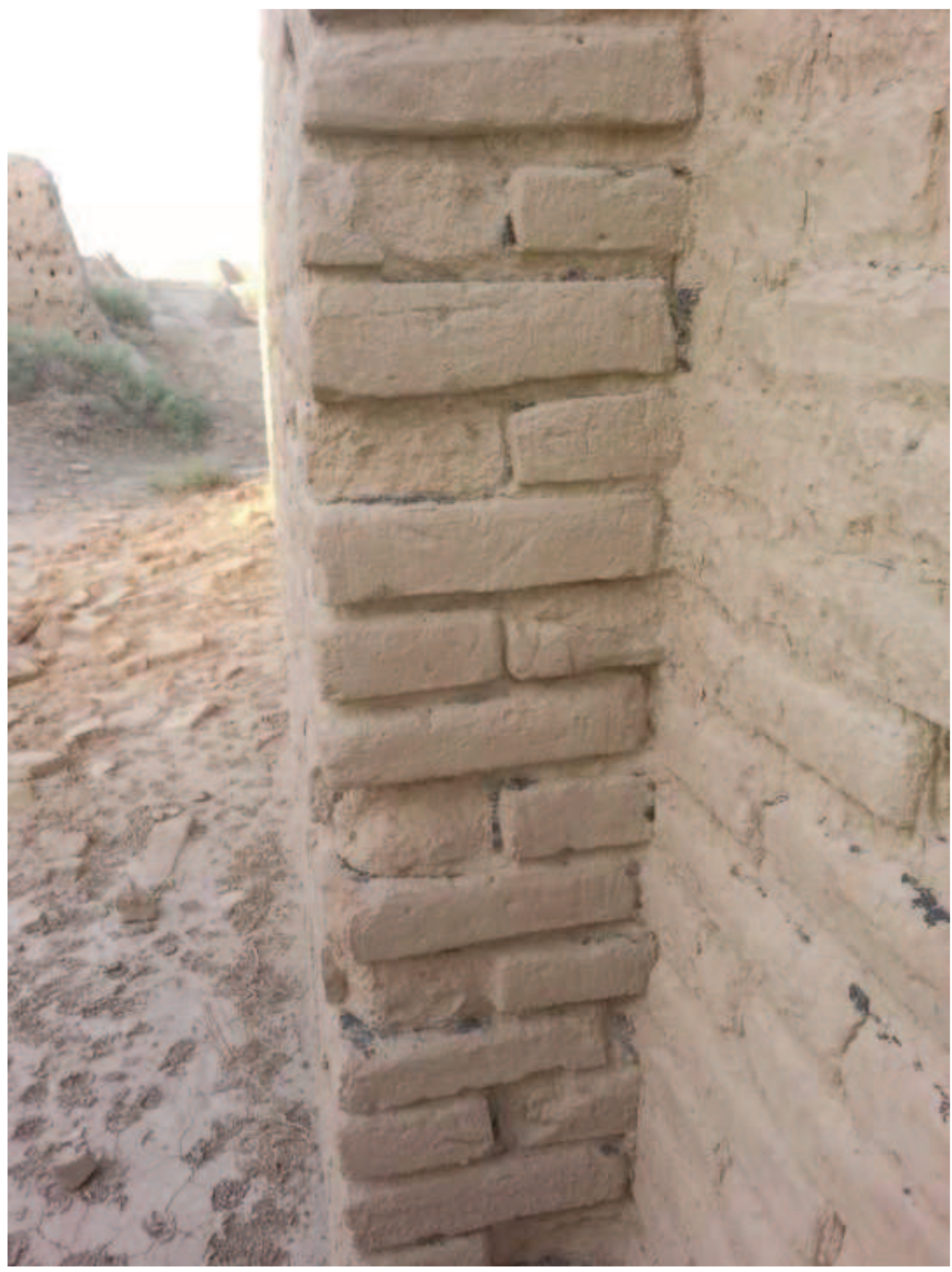


Figure-5-b
Click here to download high resolution image

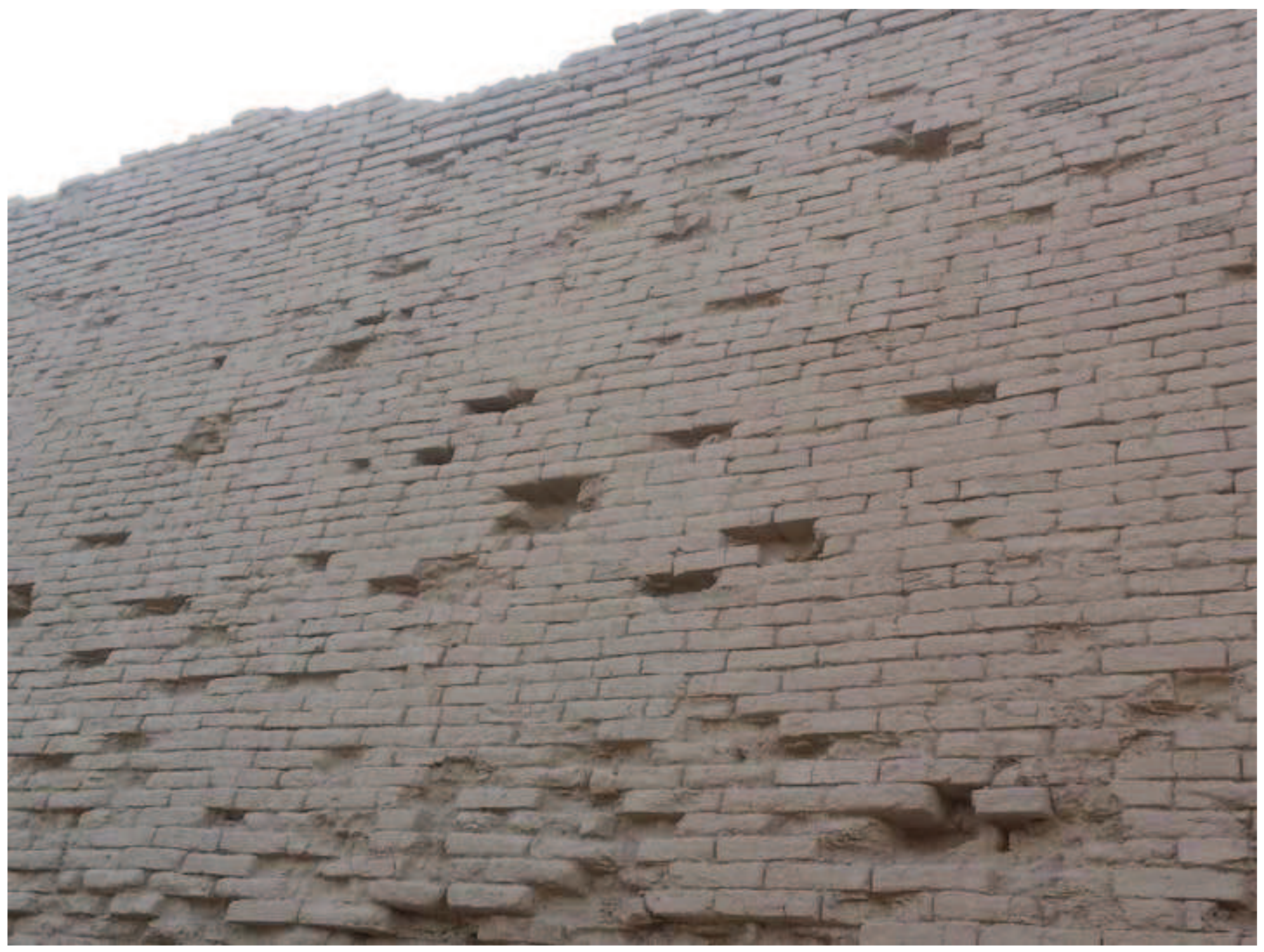

Figure-5-b

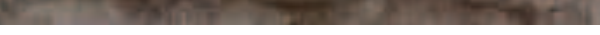
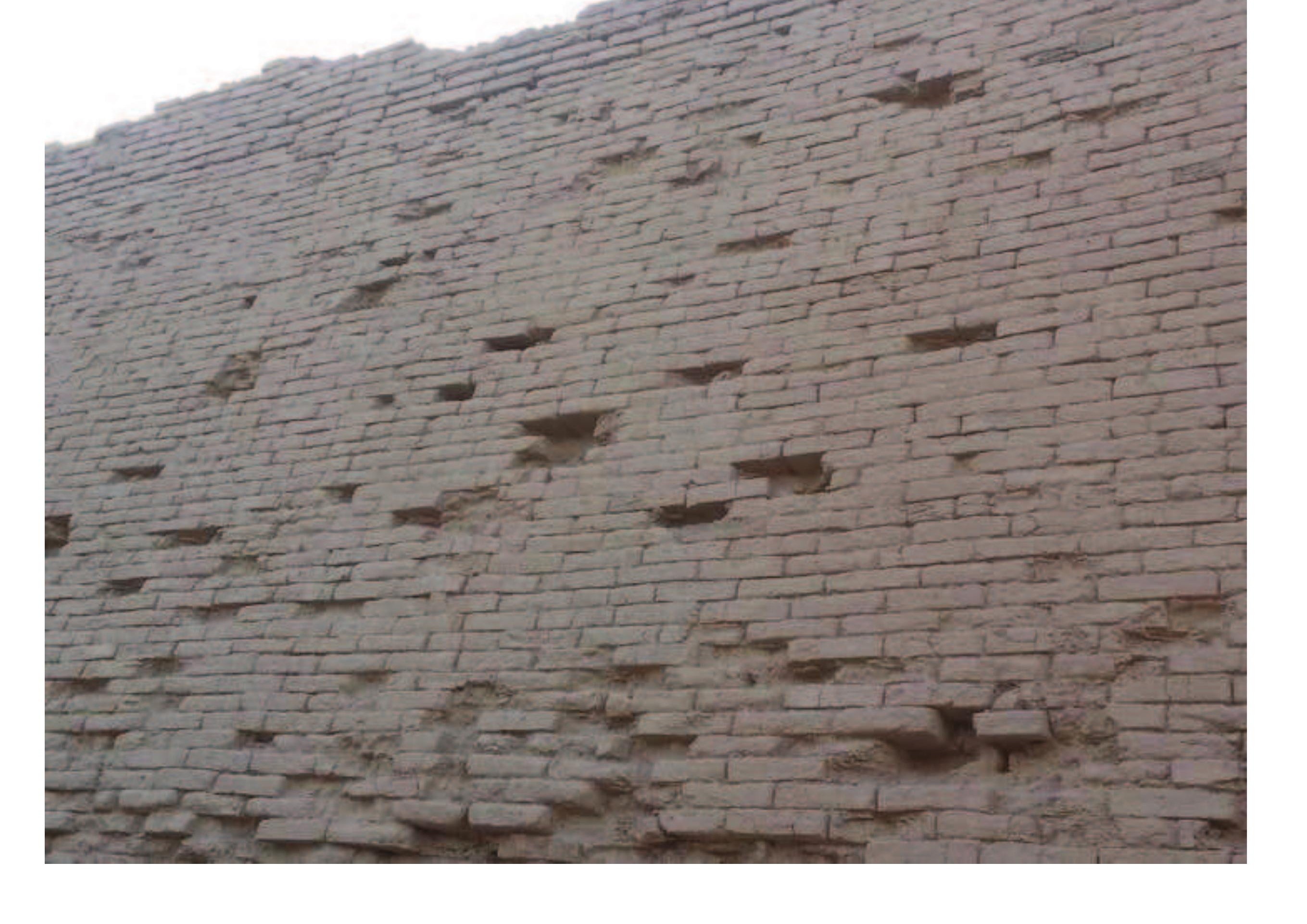


\section{Cavity filled with clay}

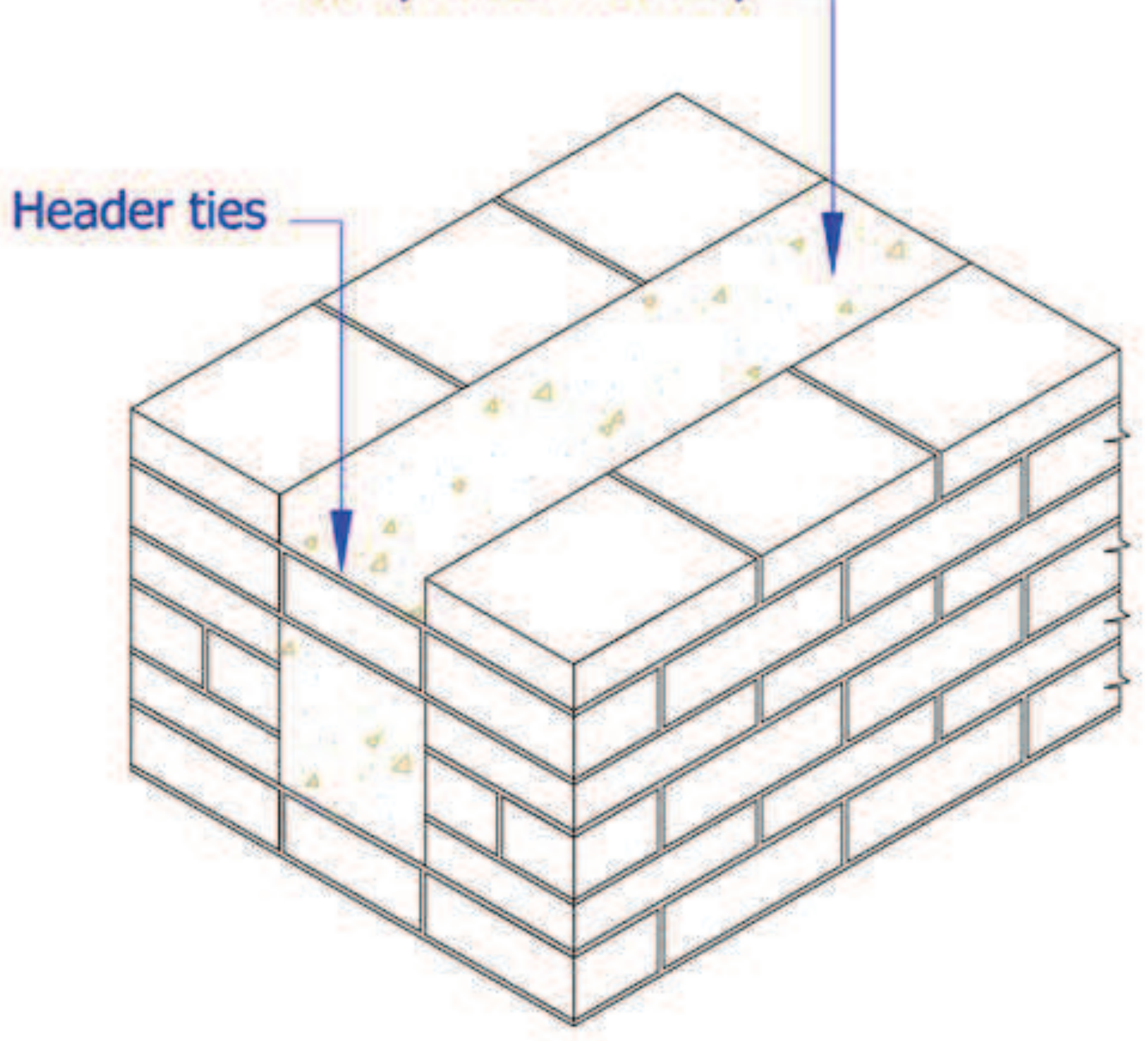


Click here to download high resolution image

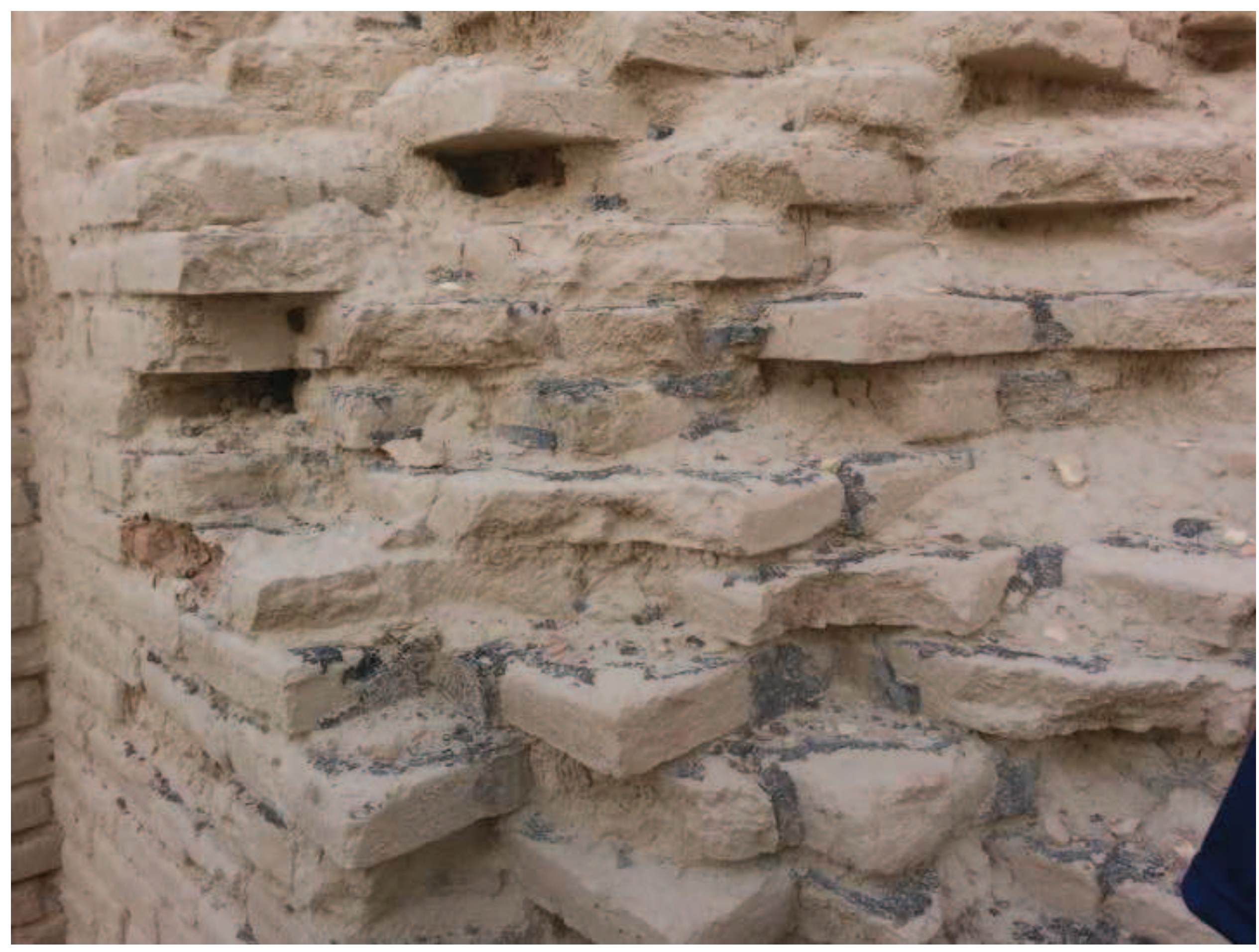




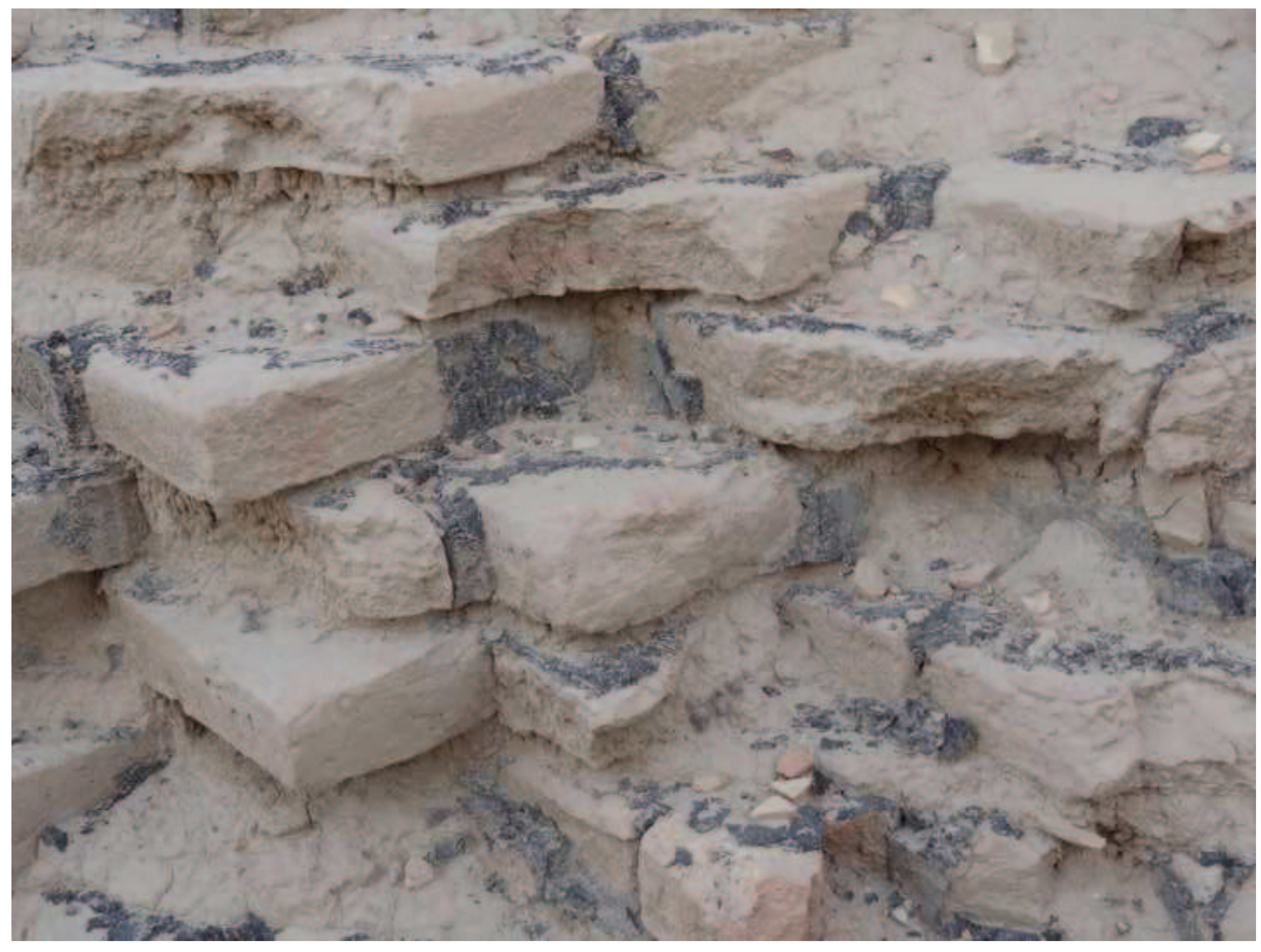

\section{Click here to download high resolution image}




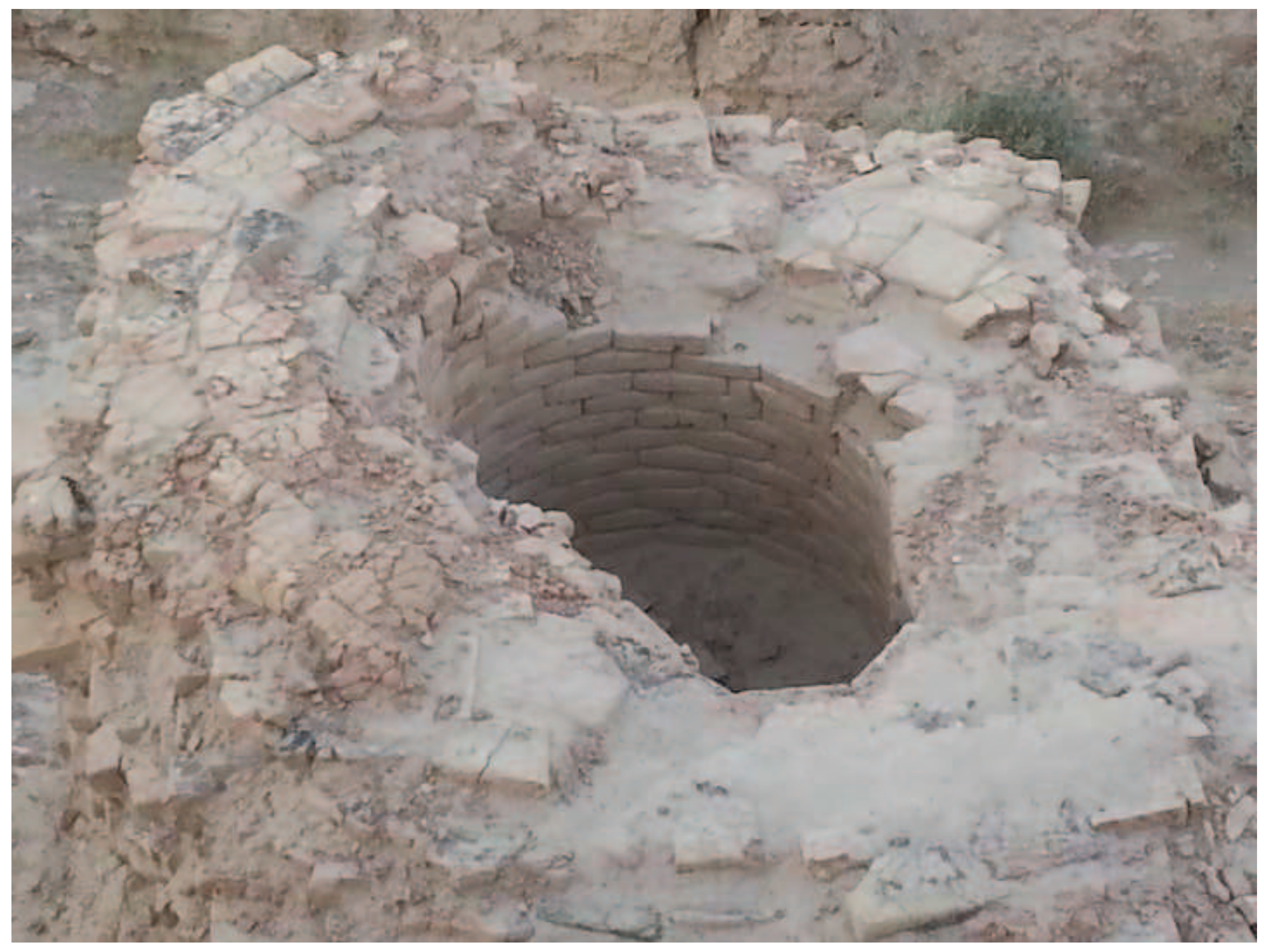

Figure-8-a 
Click here to download high resolution image

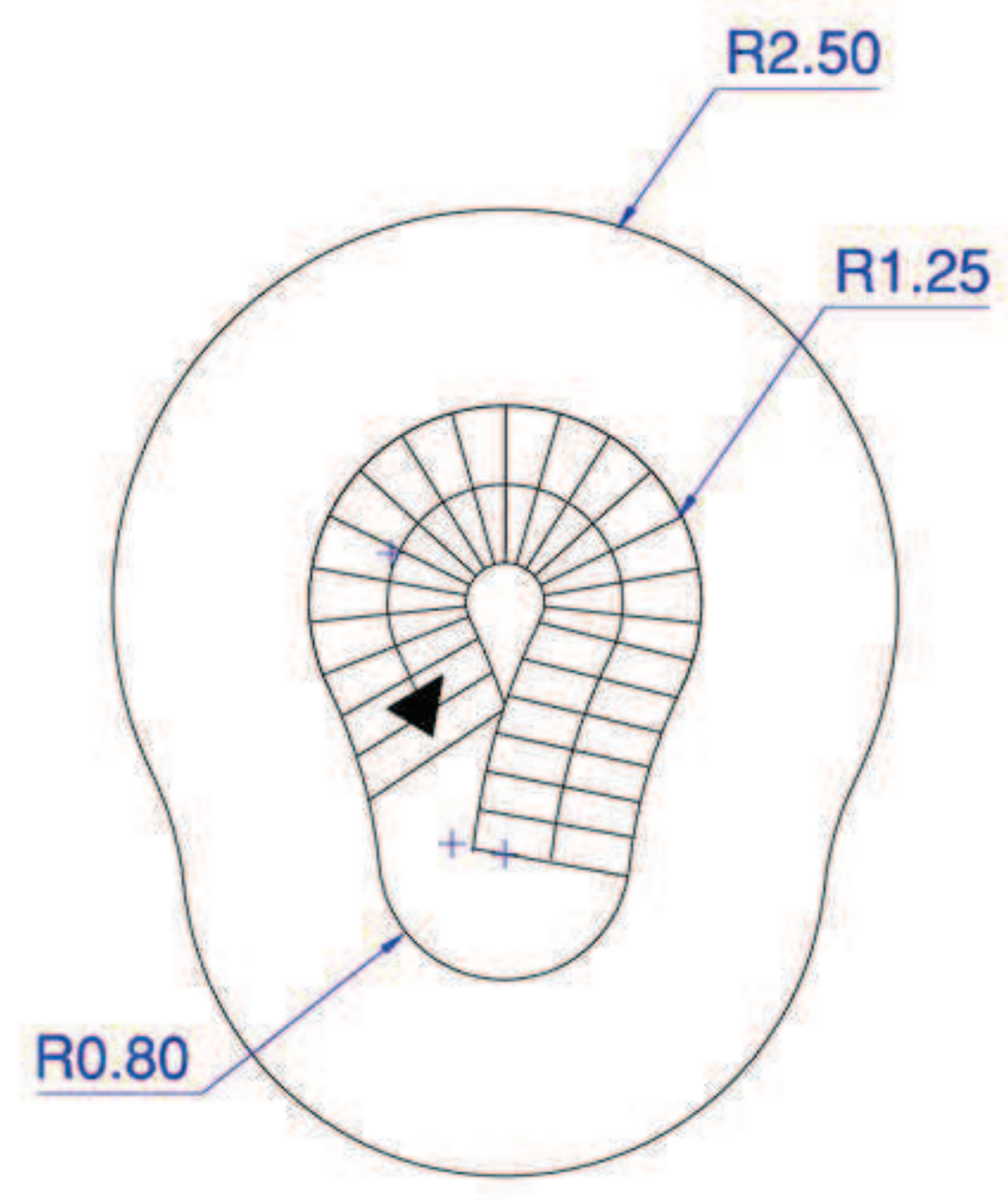




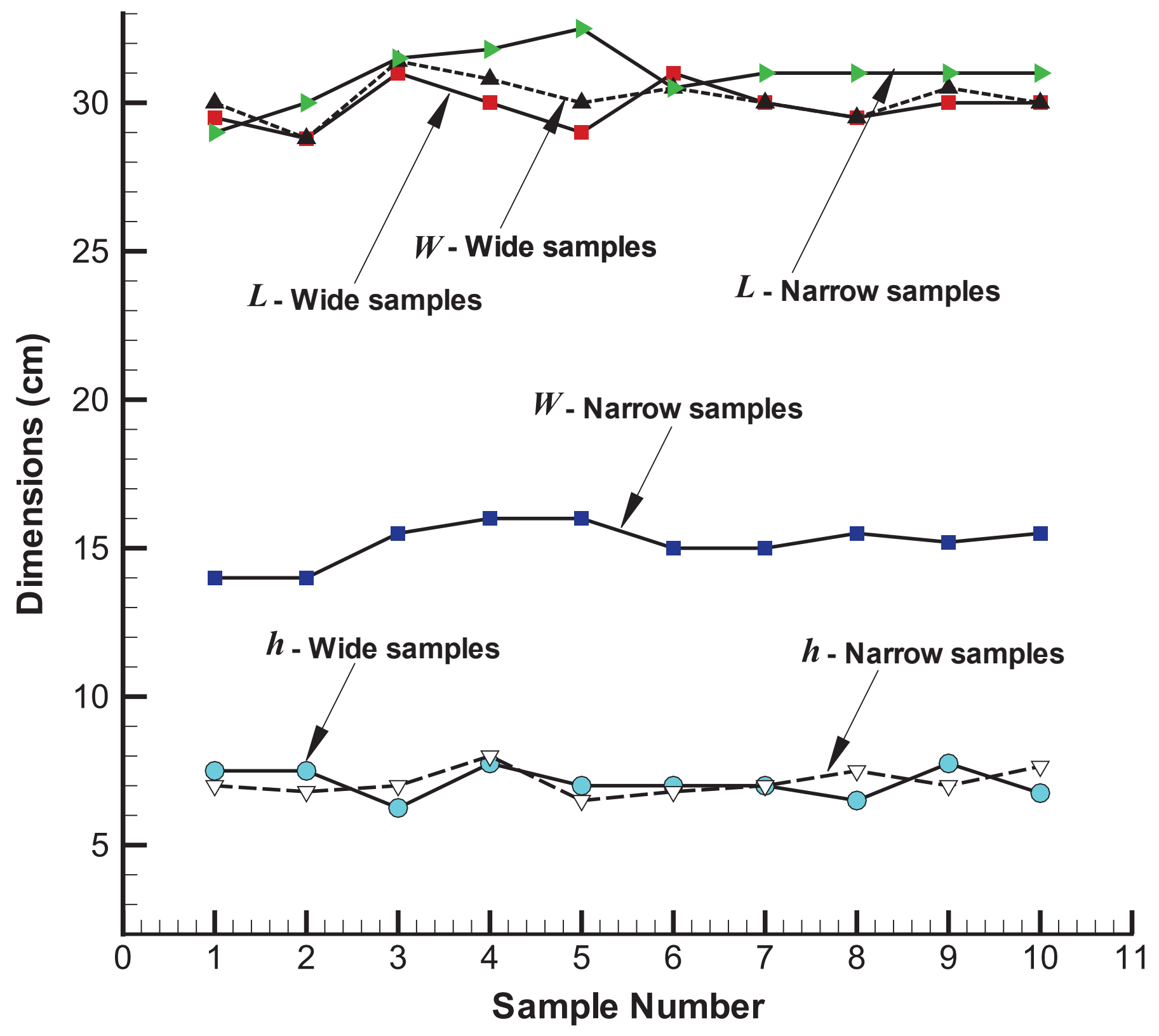




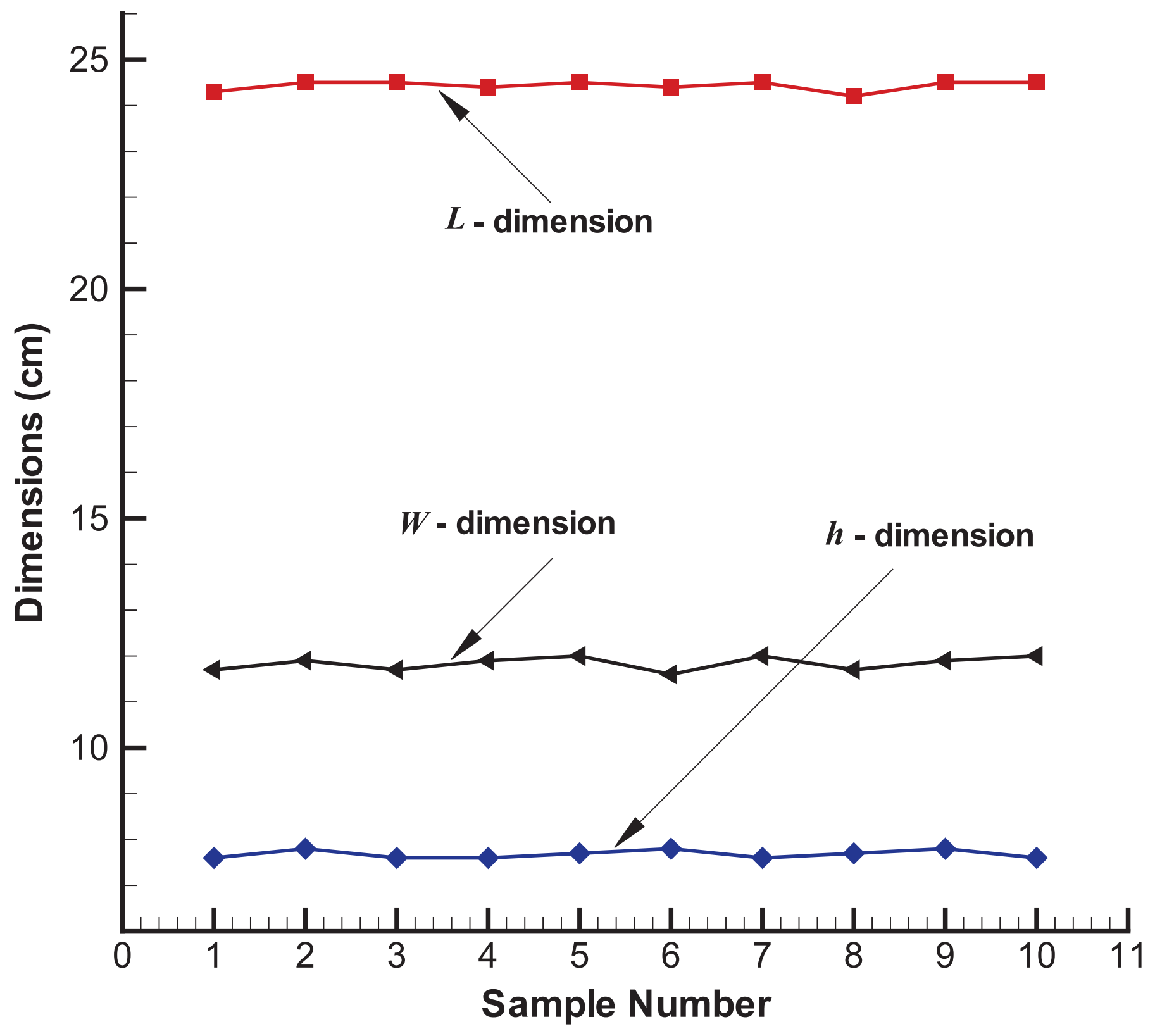




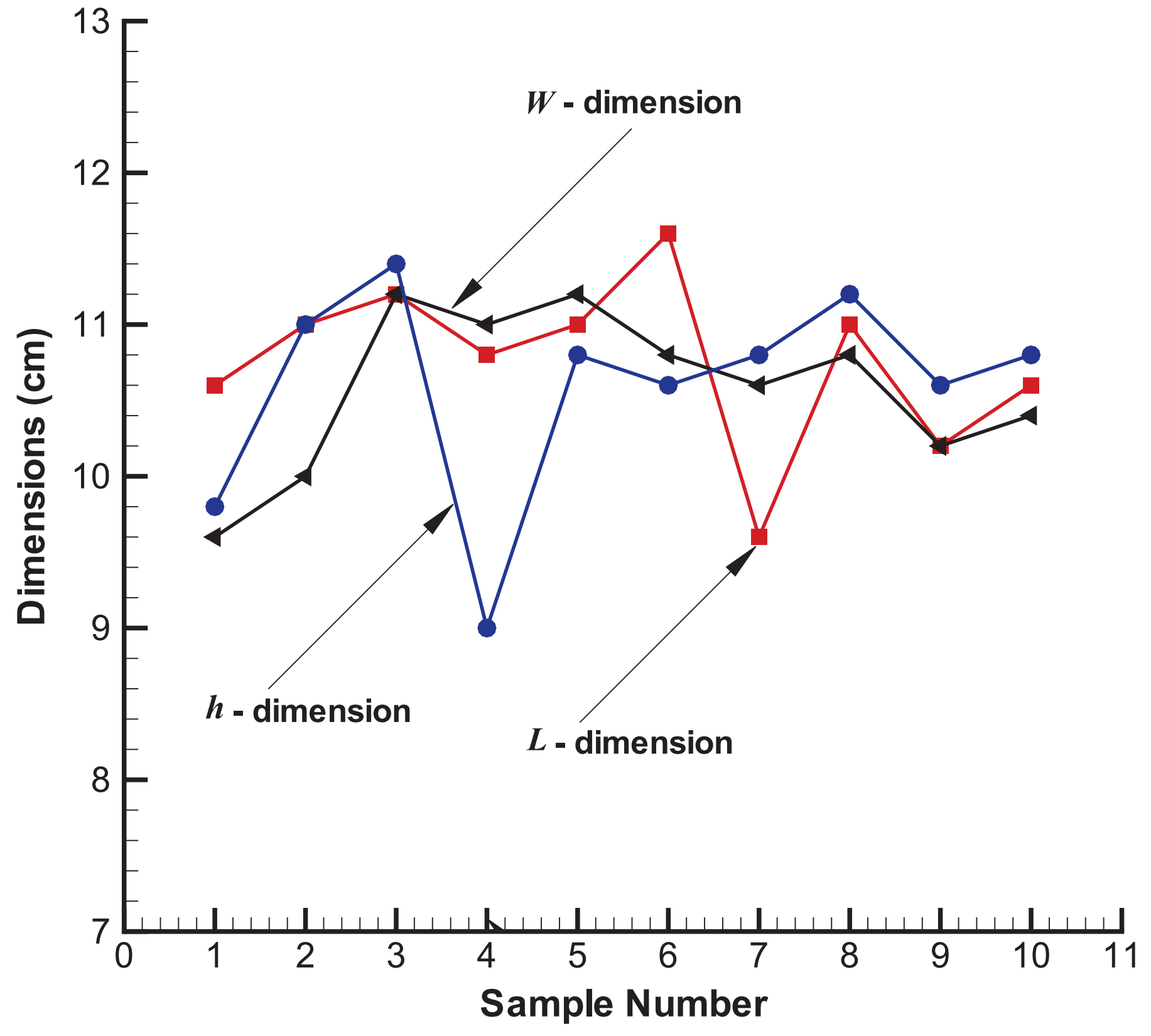




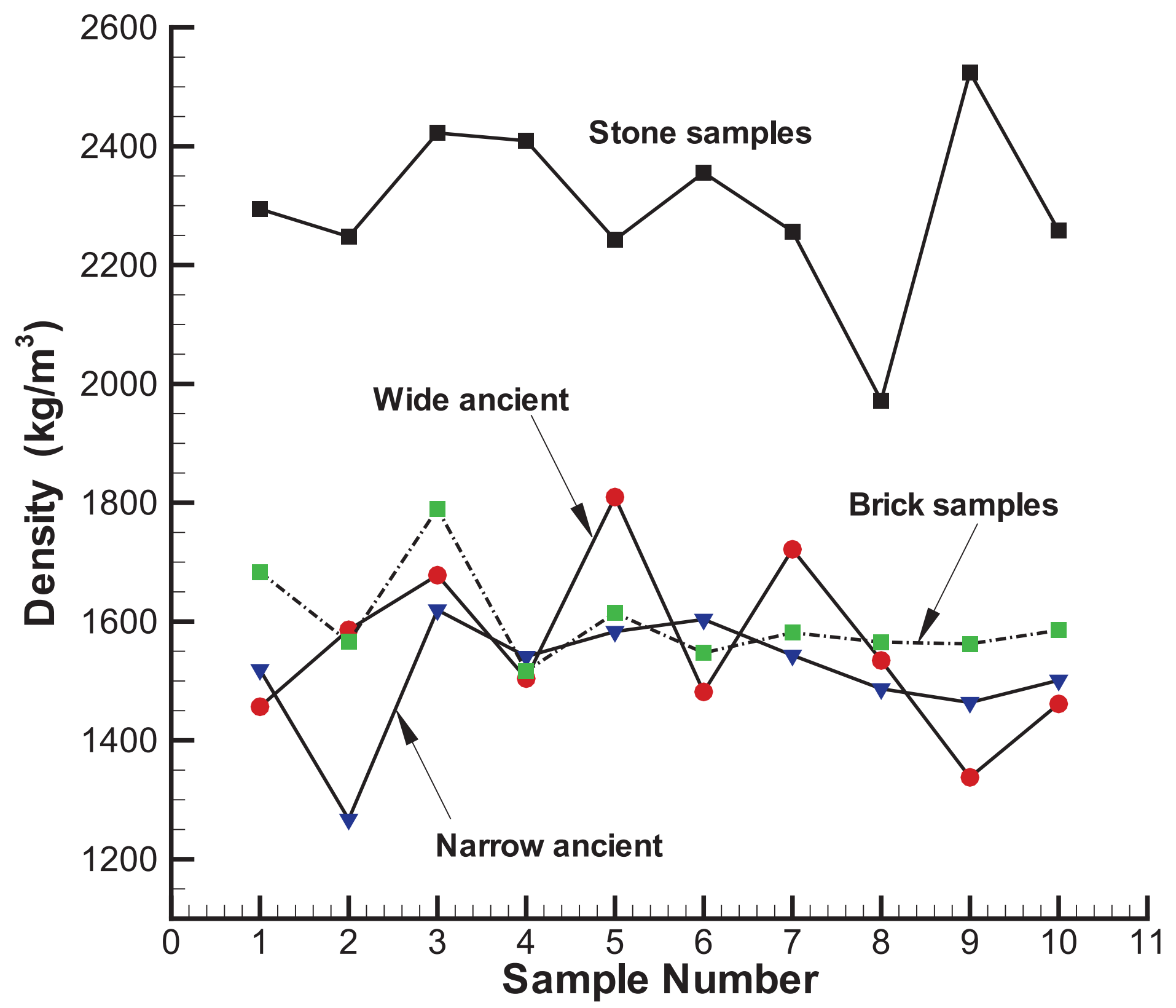




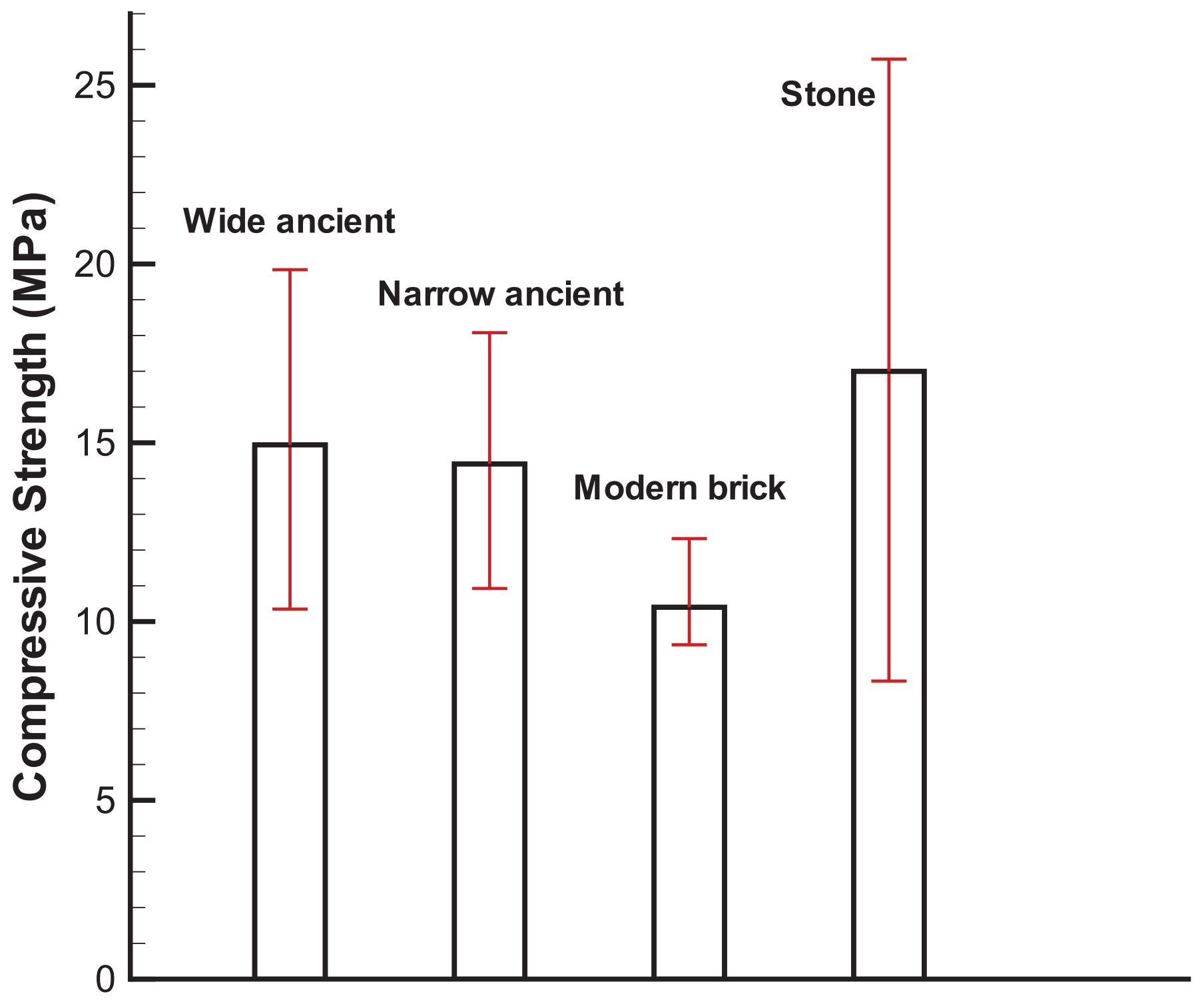




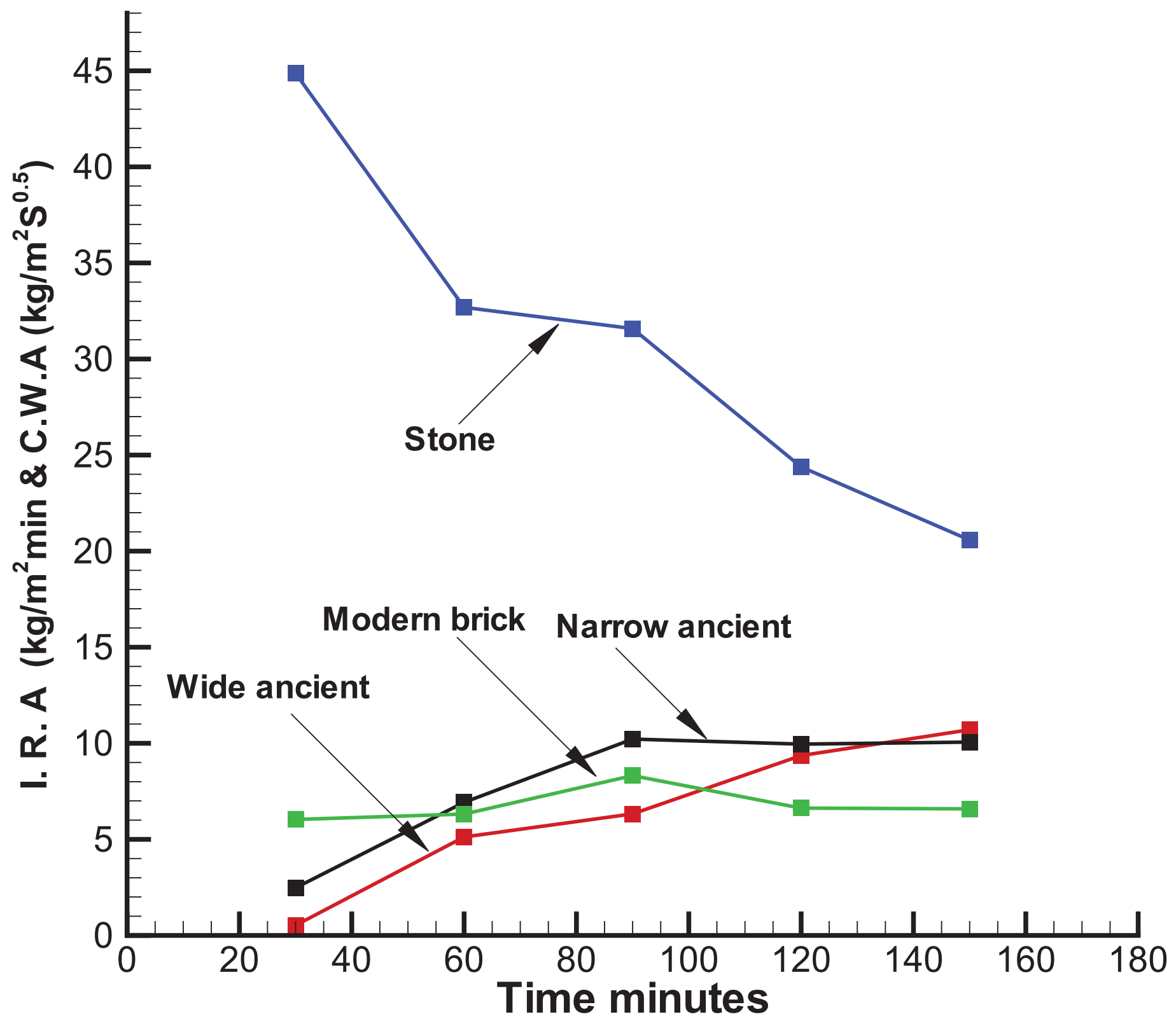




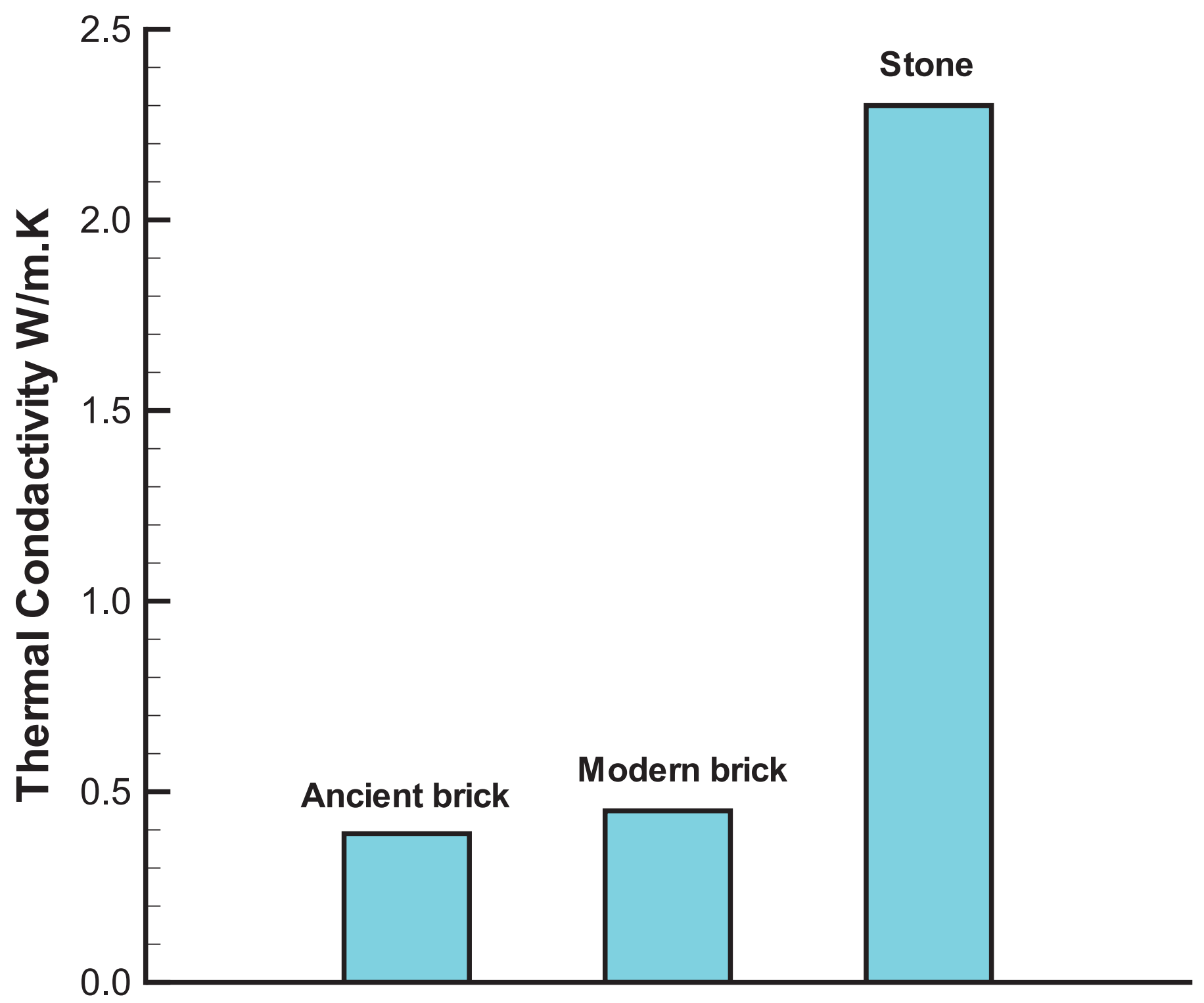




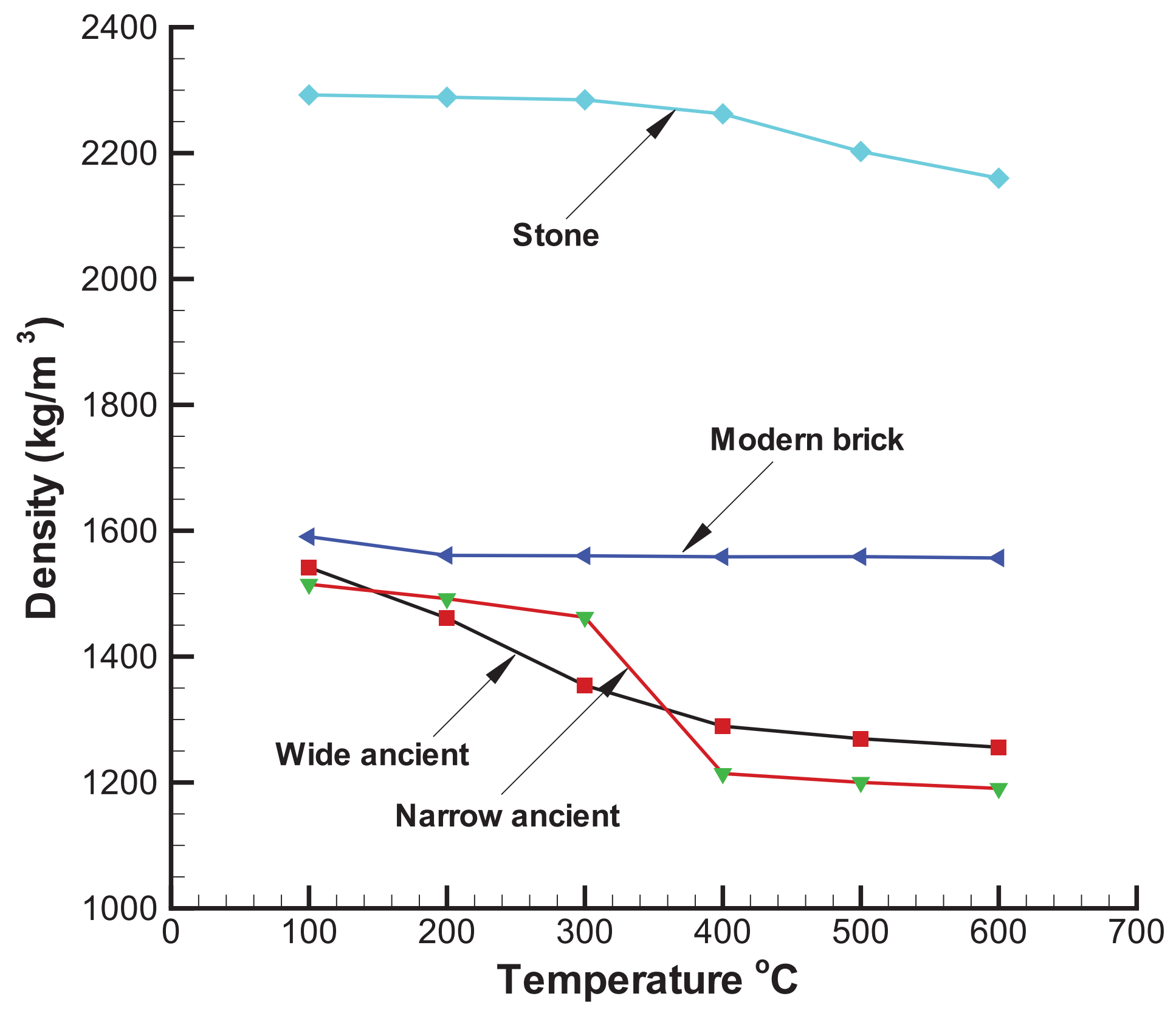

